\title{
Standardised soil profile data to support global mapping and modelling (WoSIS snapshot 2019)
}

\author{
Niels H. Batjes, Eloi Ribeiro, and Ad van Oostrum \\ ISRIC - World Soil Information, Wageningen, 6708 PB, the Netherlands \\ Correspondence: Niels H. Batjes (niels.batjes@isric.org)
}

Received: 6 September 2019 - Discussion started: 16 September 2019

Revised: 17 December 2019 - Accepted: 9 January 2020 - Published: 10 February 2020

\begin{abstract}
The World Soil Information Service (WoSIS) provides quality-assessed and standardised soil profile data to support digital soil mapping and environmental applications at broadscale levels. Since the release of the first "WoSIS snapshot", in July 2016, many new soil data were shared with us, registered in the ISRIC data repository and subsequently standardised in accordance with the licences specified by the data providers. Soil profile data managed in WoSIS were contributed by a wide range of data providers; therefore, special attention was paid to measures for soil data quality and the standardisation of soil property definitions, soil property values (and units of measurement) and soil analytical method descriptions. We presently consider the following soil chemical properties: organic carbon, total carbon, total carbonate equivalent, total nitrogen, phosphorus (extractable $\mathrm{P}$, total $\mathrm{P}$ and $\mathrm{P}$ retention), soil $\mathrm{pH}$, cation exchange capacity and electrical conductivity. We also consider the following physical properties: soil texture (sand, silt, and clay), bulk density, coarse fragments and water retention. Both of these sets of properties are grouped according to analytical procedures that are operationally comparable. Further, for each profile we provide the original soil classification (FAO, WRB, USDA), version and horizon designations, insofar as these have been specified in the source databases. Measures for geographical accuracy (i.e. location) of the point data, as well as a first approximation for the uncertainty associated with the operationally defined analytical methods, are presented for possible consideration in digital soil mapping and subsequent earth system modelling. The latest (dynamic) set of quality-assessed and standardised data, called "wosis_latest", is freely accessible via an OGC-compliant WFS (web feature service). For consistent referencing, we also provide time-specific static "snapshots". The present snapshot (September 2019) is comprised of 196498 geo-referenced profiles originating from 173 countries. They represent over 832000 soil layers (or horizons) and over 5.8 million records. The actual number of observations for each property varies (greatly) between profiles and with depth, generally depending on the objectives of the initial soil sampling programmes. In the coming years, we aim to fill gradually gaps in the geographic distribution and soil property data themselves, this subject to the sharing of a wider selection of soil profile data for so far under-represented areas and properties by our existing and prospective partners. Part of this work is foreseen in conjunction within the Global Soil Information System (GloSIS) being developed by the Global Soil Partnership (GSP). The "WoSIS snapshot - September 2019" is archived and freely accessible at https://doi.org/10.17027/isric-wdcsoils.20190901 (Batjes et al., 2019).
\end{abstract}




\section{Introduction}

According to a recent review, so far over 800000 soil profiles have been rescued and compiled into databases over the past few decades (Arrouays et al., 2017). However, only a fraction thereof is readily accessible (i.e. shared) in a consistent format for the greater benefit of the international community. This paper describes procedures for preserving, qualityassessing, standardising and subsequently providing consistent world soil data to the international community, as developed in the framework of the Data or WoSIS (World Soil Information Service) project since the release of the first snapshot in 2016 (Batjes et al., 2017); this collaborative project draws on an increasingly large complement of shared soil profile data. Ultimately, WoSIS aims to provide consistent harmonised soil data, derived from a wide range of legacy holdings as well as from more recently developed soil datasets derived from proximal sensing (e.g. soil spectral libraries; see Terhoeven-Urselmans et al., 2010; Viscarra Rossel et al., 2016), in an interoperable mode and preferably within the setting of a federated, global soil information system (GLOSIS; see GSP-SDF, 2018).

We follow the definition of harmonisation used by the Global Soil Partnership (GSP, Baritz et al., 2014). It encompasses "providing mechanisms for the collation, analysis and exchange of consistent and comparable global soil data and information". The following domains need to be considered according to GSP's definition: (a) soil description, classification, and mapping; (b) soil analyses; (c) exchange of digital soil data; and (d) interpretations. In view of the breadth and magnitude of the task, as indicated earlier (Batjes et al., 2017), we have restricted ourselves to the standardisation of soil property definitions, soil analytical method descriptions and soil property values (i.e. measurement units). We have expanded the number of soil properties considered in the preceding snapshot, i.e. those listed in the GlobalSoilMap (2015) specifications, gradually working towards the range of soil properties commonly considered in other global soil data compilation programmes (Batjes, 2016; FAO et al., 2012; van Engelen and Dijkshoorn, 2013).

Soil characterisation data, such as $\mathrm{pH}$ and bulk density, are collated according to a wide range of analytical procedures. Such data can be more appropriately used when the procedures for their collection, analysis and reporting are well understood. As indicated by USDA Soil Survey Staff (2011), results differ when different analytical methods are used, even though these methods may carry the same name (e.g. soil $\mathrm{pH}$ ) or concept. This complicates, or sometimes precludes, comparison of one set of data with another if it is not known how both sets were collected and analysed. Hence, our use of "operational definitions" for soil properties that are linked to specific methods. As an example, we may consider the "pH of a soil". This requires information on sample pretreatment, soil / solution ratio and description of solution (e.g. $\mathrm{H}_{2} \mathrm{O}, 1 \mathrm{M} \mathrm{KCl}, 0.02 \mathrm{M} \mathrm{CaCl}_{2}$, or $1 \mathrm{M} \mathrm{NaF}$ ) to be fully understood. The $\mathrm{pH}$ level measured in sodium fluoride $(\mathrm{pH}$ $\mathrm{NaF}$ ), for example, provides a measure for the phosphorus (P) retention of a soil, whereas $\mathrm{pH}$ measured in water $\mathrm{pH}$ $\mathrm{H}_{2} \mathrm{O}$ ) is an indicator for soil nutrient status. Consequently, in WoSIS, soil properties are defined by the analytical methods and the terminology used, based on common practice in soil science.

This paper discusses methodological changes in the WoSIS workflow since the release of the preceding snapshot (Batjes et al., 2017), describes the data screening procedure, provides a detailed overview of the database content, explains how the new set of standardised data can be accessed and outlines future developments. The data model for the underpinning PostgreSQL database itself is described in a recently updated procedures manual (Ribeiro et al., 2018); these largely technical aspects are considered beyond the scope of this paper.

Quality-assessed data provided through WoSIS can be (and have been) used for various purposes. For example, as point data for making soil property maps at various spatialscale levels, using digital soil mapping techniques (Arrouays et al., 2017; Guevara et al., 2018; Hengl et al., 2017a, b; Moulatlet et al., 2017). Such property maps, for example, can be used to study global effects of soil and climate on leaf photosynthetic traits and rates (Maire et al., 2015), generate maps of root zone plant-available water capacity (Leenaars et al., 2018) in support of yield gap analyses (van Ittersum et al., 2013), assess impacts of long-term human land use on world soil carbon stocks (Sanderman et al., 2017), or the effects of tillage practices on soil gaseous emissions (Lutz et al., 2019). In turn, this type of information can help to inform global conventions such as the UNCCD (United Nations Convention to Combat Desertification) and UNFCCC (United Nations Framework Convention on Climate Change) so that policymakers and business leaders can make informed decisions about environmental and societal well-being.

\section{WoSIS workflow}

The overall workflow for acquiring, ingesting and processing data in WoSIS has been described in an earlier paper (Batjes et al., 2017). To avoid repetition, we will only name the main steps here (Fig. 1). These are, successively, (a) store submitted datasets with their metadata (including the licence defining access rights) in the ISRIC Data Repository; (b) import all datasets "as is" into PostgreSQL; (c) ingest the data into the WoSIS data model, including basic data quality assessment and control; (d) standardise the descriptions for the soil analytical methods and the units of measurement; and (e) ultimately, upon final consistency checks, distribute the quality-assessed and standardised data via WFS (web feature service) and other formats (e.g. TSV for snapshots).

As indicated, datasets shared with our centre are first stored in the ISRIC Data Repository, together with their 

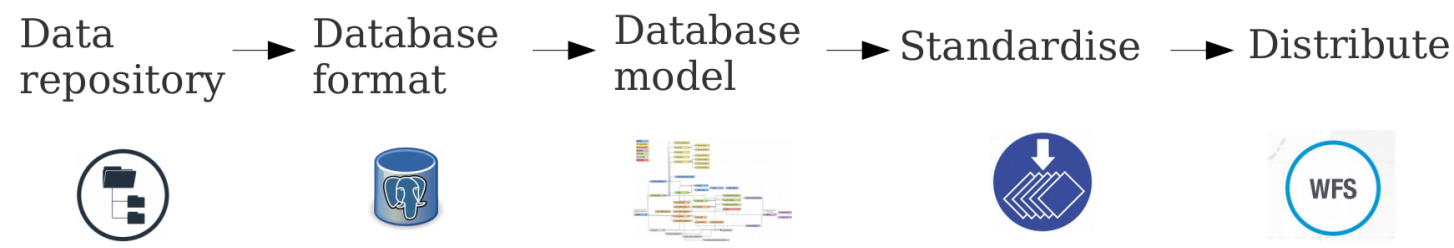

Figure 1. Schematic representation of the WoSIS workflow for safeguarding and processing disparate soils datasets.

metadata (currently representing some 452000 profiles) and the licence and data-sharing agreement in particular, in line with the ISRIC Data Policy (ISRIC, 2016). For the WoSIS standardisation workflow proper, we only consider those datasets (or profiles) that have a "non-restrictive" Creative Commons (CC) licence as well as a defined complement of attributes (see Appendix A). Non-restrictive has been defined here as at least a CC-BY (attribution) or CC-BY-NC (attribution non-commercial) licence. Presently, this corresponds with data for some 196498 profiles (i.e. profiles that have the right licence and data for at least one of the standard soil properties). Alternatively, some datasets may only be used for digital soil mapping using SoilGrids ${ }^{\mathrm{TM}}$, corresponding with an additional 42000 profiles, corresponding to some $18 \%$ of the total amount of standardised profiles $(\sim 238000)$. Although the latter profiles are quality-assessed and standardised following the regular WoSIS workflow, they are not distributed to the international community in accordance with the underpinning licence agreements; as such, their description is beyond the scope of the present paper. Finally, several datasets have licences indicating that they should only be safeguarded in the repository; inherently, these are not being used for any data processing.

\section{Data screening, quality control and standardisation}

\subsection{Consistency checks}

Soil profile data submitted for consideration in WoSIS were collated according to various national or international standards and presented in various formats (from paper to digital). Further, they are of varying degrees of completeness, as discussed below. Proper documentation of the provenance and identification of each dataset and, ideally, each observation or measurement is necessary to allow for efficient processing of the source data. The following need to be specified: profiles and layers referenced by feature $(x-y-z)$ and time $(t)$, attribute (class, site, layer field and layer lab), method, and value, including units of expression.

To be considered in the actual WoSIS standardisation workflow, each profile must meet several criteria (Table 1). First, we assess if each profile is geo-referenced, has (consistently) defined upper and lower depths for each layer (or horizon), and has data for at least some soil properties (e.g. sand, silt, clay and $\mathrm{pH}$ ). Having a soil (taxonomic) classi-
Table 1. Basic requirements for considering soil profiles in the WoSIS standardisation workflow.

\begin{tabular}{|c|c|c|c|c|c|}
\hline Case & $(x, y)$ & $\begin{array}{l}\text { Layer } \\
\text { depth }\end{array}$ & $\begin{array}{c}\text { Soil } \\
\text { properties }^{\mathrm{a}}\end{array}$ & Classification & Keep \\
\hline 1 & + & + & + & + & Yes \\
\hline 2 & + & + & + & - & Yes \\
\hline 3 & + & - & - & + & Yes $^{\mathrm{a}}$ \\
\hline 4 & - & + & + & + & Yes/no ${ }^{b}$ \\
\hline 5 & - & + & + & - & Yes/no ${ }^{b}$ \\
\hline 6 & + & + & - & - & No \\
\hline 7 & + & - & + & - & $\mathrm{No}^{\mathrm{c}}$ \\
\hline
\end{tabular}

${ }^{a}$ Such profiles may be used to generate maps of soil taxonomic classes using SoilGrids ${ }^{\mathrm{TM}}$ (Hengl et al., 2017b). ${ }^{\mathrm{b}}$ Such profiles (geo-referenced solely according to their country of origin) may be useful for developing pedotransfer functions. Hence, they are standardised, though they are not distributed with the snapshot, as they lack $(x, y)$ coordinates. ${ }^{\mathrm{c}}$ Lacking information on the depth of sampling (i.e. layer), the different soil properties cannot be meaningfully grouped to develop pedotransfer functions.

fication is considered desirable (case 1) but not mandatory (case 2). Georeferenced profiles for which only the classification is specified can still be useful for mapping of soil taxonomic classes (case 3). Alternatively, profiles without any geo-reference may still prove useful to develop pedotransfer functions (case 4 and 5); however, they cannot be served through WFS (because there is no geometry, $x, y$ ). The remaining cases (6 and 7) are automatically excluded from the WoSIS workflow. This first broad consistency check led to the exclusion of over 50000 profiles from the initial complement of soil profiles.

Consistency in layer depth (i.e. sequential increase in the upper and lower depth reported for each layer down the profile) is checked using automated procedures (see Sect. 3.2). In accord with current internationally accepted conventions, such depth increments are given as "measured from the surface, including organic layers and mineral covers" (FAO, 2006; Schoeneberger et al., 2012). Prior to 1993, however, the beginning (zero datum) of the profile was set at the top of the mineral surface (the solum proper), except for "thick" organic layers as defined for peat soils (FAO-ISRIC, 1986; FAO, 1977). Organic horizons were recorded as above and mineral horizons recorded as below, relative to the mineral surface (Schoeneberger et al., 2012, pp. 2-6). Insofar as is possible, such "surficial litter" layers are flagged in WoSIS as an auxiliary variable (see Appendix B) so that they may 
be filtered out during auxiliary computations of soil organic carbon stocks, for example.

\subsection{Flagging duplicate profiles}

Several source materials, such as the harmonised WISE soil profile database (Batjes, 2009), the Africa Soil Profile Database (AfSP, Leenaars et al., 2014) and the dataset collated by the International Soil Carbon Network (ISCN, Nave et al., 2017) are compilations of shared soil profile data. These three datasets, for example, contain varying amounts of profiles derived from the National Cooperative Soil Survey database (USDA-NCSS, 2018), an important source of freely shared, primary soil data. The original NCSS profile identifiers, however, may not always have been preserved "as is" in the various data compilations.

To avoid duplication in the WoSIS database, soil profiles located within $100 \mathrm{~m}$ of each other are flagged as possible duplicates. Upon additional, semi-automated checks concerning the first three layers (upper and lower depth), i.e. sand, silt and clay content, the duplicates with the least comprehensive component of attribute data are flagged and excluded from further processing. When still in doubt at this stage, additional visual checks are made with respect to other commonly reported soil properties, such as $\mathrm{pH}_{\text {water }}$ and organic carbon content. This laborious, yet critical, screening process (see Ribeiro et al., 2018) led to the exclusion of some 50000 additional profiles from the initial complement of soil profile data.

\subsection{Ensuring naming consistency}

The next key stage has been the standardisation of soil property names to the WoSIS conventions, as well as the standardisation of the soil analytical methods descriptions themselves (see Appendix A). Quality checks consider the units of measurement, plausible ranges for defined soil properties (e.g. soil $\mathrm{pH}$ cannot exceed 14) using checks on minimum, average and maximum values for each source dataset. Data that do not fulfil the requirements are flagged and not considered further in the workflow, unless the observed "inconsistencies" can easily be fixed (e.g. blatant typos in $\mathrm{pH}$ values). The whole procedure, with flowcharts and option tables, is documented in the WoSIS Procedures Manual (see Appendices D, E and F in Ribeiro et al., 2018).

Presently, we standardise the following set of soil properties in WoSIS.

- Chemical. Organic carbon, total carbon (i.e. organic plus inorganic carbon), total nitrogen, total carbonate equivalent (inorganic carbon), soil $\mathrm{pH}$, cation exchange capacity, electrical conductivity and phosphorus (extractable $\mathrm{P}$, total $\mathrm{P}$ and $\mathrm{P}$ retention).

- Physical. Soil texture (sand, silt and clay), coarse fragments, bulk density and water retention.
It should be noted that all measurement values are reported as recorded in the source data, subsequent to the above consistency checks (and standardisation of the units of measurement to the target units; see Appendix A). As such, we neither apply "gap-filling" procedures in WoSIS, e.g. when only the sand and silt fractions are reported, nor do we apply pedotransfer functions to derive soil hydrological properties. This next stage of data processing is seen as the responsibility of the data users (modellers) themselves, as the required functions or means of depth-aggregating the layer data will vary with the projected use(s) of the standardised data (see Finke, 2006; Hendriks et al., 2016; Van Looy et al., 2017).

\subsection{Providing measures for geographic and attribute accuracy}

It is well known that "soil observations used for calibration and interpolation are themselves not error free" (Baroni et al., 2017; Cressie and Kornak, 2003; Folberth et al., 2016; Grimm and Behrens, 2010; Guevara et al., 2018; Hengl et al., 2017b; Heuvelink, 2014; Heuvelink and Brown, 2006). Hence, we provide measures for the geographic accuracy of the point locations as well as the accuracy of the laboratory measurements for possible consideration in digital soil mapping and subsequent earth system modelling (Dai et al., 2019).

All profile coordinates in WoSIS are presented according to the World Geodetic System (i.e. WGS84, EPSG code 4326). These coordinates were converted from a diverse range of national projections. Further, the source referencing may have been in decimal degrees (DD) or expressed in degrees, minutes, and seconds (DMS) for both latitude and longitude. The (approximate) accuracy of georeferencing in WoSIS is given in decimal degrees. If the source only provided degrees, minutes, and seconds (DMS) then the geographic accuracy is set at 0.01 ; if seconds (DM) are missing it is set at 0.1; and if seconds and minutes (D) are missing it is set at 1 . For most profiles ( $86 \%$; see Table 2), the approximate accuracy of the point locations, as inferred from the original coordinates given in the source datasets, is less than $10 \mathrm{~m}$ (total $=196498$ profiles; see Sect. 4). Typically, the geo-referencing of soil profiles described and sampled before the advent of GPS (Global Positioning Systems) in the 1970s is less accurate; sometimes we just do not know the "true" accuracy. Digital soil mappers should duly consider the inferred geometric accuracy of the profile locations in their applications (Grimm and Behrens, 2010), since the soil observations and covariates may not actually correspond (Cressie and Kornak, 2003) in both space and time (see Sect. 4, second paragraph).

As indicated, soil data considered in WoSIS have been analysed according to a wide range of analytical procedures and in different laboratories. An indication of the measurement uncertainty is thus desired; soil-laboratory-specific Quality Management Systems (van Reeuwijk, 1998), as well 
Table 2. Approximate accuracy of the profile locations.

\begin{tabular}{lrlrr}
\hline $\begin{array}{l}\text { Decimal } \\
\text { places }\end{array}$ & $\begin{array}{r}\text { Decimal } \\
\text { degrees }\end{array}$ & $\begin{array}{l}\text { Approximate } \\
\text { precision }\end{array}$ & \multicolumn{2}{c}{$\begin{array}{c}\text { Number of } \\
\text { profiles }\end{array}$} \\
\cline { 3 - 5 } & & & $n$ & $\%$ \\
\hline 7 & 0.0000001 & $1 \mathrm{~cm}$ & 1345 & 0.7 \\
6 & 0.000001 & $10 \mathrm{~cm}$ & 84945 & 43.2 \\
5 & 0.00001 & $1 \mathrm{~m}$ & 74024 & 37.7 \\
4 & 0.0001 & $10 \mathrm{~m}$ & 9158 & 4.7 \\
3 & 0.001 & $100 \mathrm{~m}$ & 8108 & 4.1 \\
2 & 0.01 & $1 \mathrm{~km}$ & 10915 & 5.6 \\
1 & 0.1 & $10 \mathrm{~km}$ & 6458 & 3.2 \\
0 & 1 & $100 \mathrm{~km}$ & 1545 & 0.8 \\
\hline
\end{tabular}

as laboratory proficiency-testing (PT, Magnusson and Örnemark, 2014; Munzert et al., 2007; WEPAL, 2019), can provide this type of information. Yet, calculation of laboratoryspecific measurement uncertainty for a single method or multiple analytical methods will require several measurement rounds (years of observation) and solid statistical analyses. Overall, such detailed information is not available for the datasets submitted to the ISRIC data repository. Therefore, out of necessity, we have distilled the desired information from the PT literature (Kalra and Maynard, 1991; Rayment and Lyons, 2011; Rossel and McBratney, 1998; van Reeuwijk, 1983; WEPAL, 2019), in so far as technically feasible. For example, accuracy for bulk density measurements, both for the direct core and the clod method, has been termed "low" (though not quantified) in a recent review (AlShammary et al., 2018); using expert knowledge, we have assumed this corresponds with an uncertainty (or variability, expressed as coefficient of variation) of $35 \%$. Alternatively, for organic carbon content the mean variability was $17 \%$ (with a range of $12 \%$ to $42 \%$ ) and for "CEC (cation exchange capacity) buffered at $\mathrm{pH} 7$ " it was $18 \%$ (range $13 \%$ to $25 \%$ ) when multiple laboratories analyse a standard set of reference materials using similar operational methods (WEPAL, 2019). For soil pH measurements (log scale), we have expressed the uncertainty in terms of " $\pm \mathrm{pH}$ units".

Importantly, the figures for measurement accuracy presented in Appendix A represent first approximations. They are based on the inter-laboratory comparison of wellhomogenised reference samples for a still relatively small range of soil types. These indicative figures should be refined once laboratory-specific and method-related accuracy (i.e. systematic and random error) information is provided for the shared soil data, e.g. by using the procedures described by Eurachem (Magnusson and Örnemark, 2014). Alternatively, this type of information may be refined in the context of international laboratory PT networks, such as GLOSOLAN and WEPAL. Meanwhile, the present "first" estimates may already be considered to calculate the accuracy of digital soil maps and of any interpretations derived from them (e.g. maps of soil organic carbon stocks in support of the UNCCD Land Degradation Neutrality, LDN, effort).

\section{Spatial distribution of soil profiles and number of observations}

The present snapshot includes standardised data for 196498 profiles (Fig. 2), about twice the amount represented in the "July 2016" snapshot. These are represented by some 832000 soil layers (or horizons). In total, this corresponds with over 5.8 million records that include both numeric (e.g. sand content, soil $\mathrm{pH}$ and cation exchange capacity) and class (e.g. WRB soil classification and horizon designation) properties. The naming conventions and standard units of measurement are provided in Appendix A, and the file structure is provided in Appendix B.

Being a compilation of national soil data, the profiles were sampled over a long period of time. The dates reported in the snapshot will reflect the year the respective data were sampled and analysed: $1397(0.7 \%)$ profiles were sampled before 1920, $218(0.1 \%)$ between 1921 and 1940, 7,657 (3.9\%) between 1941 and 1960, 26,614 (13.5\%) between 1961 and 1980, 62691 (31.9\%) between 1981 and 2000, and 31084 (15.8\%) between 2001 and 2020, while the date of sampling is unknown for 66837 profiles $(34.0 \%)$. This information should be taken into consideration when linking the point data with environmental covariates, such as land use, in digital soil mapping.

The number of profiles per continent is highest for North America (73 604 versus 63066 in the "2016" snapshot), followed by Oceania (42918 versus 235), Europe (35311 versus 1,908), Africa (27688 versus 17153 ), South America (10 218 versus 8790), Asia (6704 versus 3089) and Antarctica (9, no change). These profiles come from 173 countries; the average density of observations is 1.35 profiles per $1000 \mathrm{~km}^{2}$. The actual density of observations varies greatly, both between countries (Appendix C) and within each country, with the largest densities of "shared" profiles reported for Belgium (228 profiles per $1000 \mathrm{~km}^{2}$ ) and Switzerland (265 profiles per $1000 \mathrm{~km}^{2}$ ). There are still relatively few profiles for Central Asia, Southeast Asia, Central and Eastern Europe, Russia, and the northern circumpolar region. The number of profiles by biome (R. J. Olson et al., 2001) or broad climatic region (Sayre et al., 2014), as derived from GIS overlays, is provided in Appendix D for additional information.

There are more observations for the chemical data than the physical data (see Appendix A) and the number of observations generally decreases with depth, largely depending on the objectives of the original soil surveys. The interquartile range for maximum depth of soil sampled in the field is 56$152 \mathrm{~cm}$, with a median of $110 \mathrm{~cm}$ (mean $=117 \mathrm{~cm})$. In this respect, it should be noted that some specific purpose surveys only considered the topsoil (e.g. soil fertility surveys), 


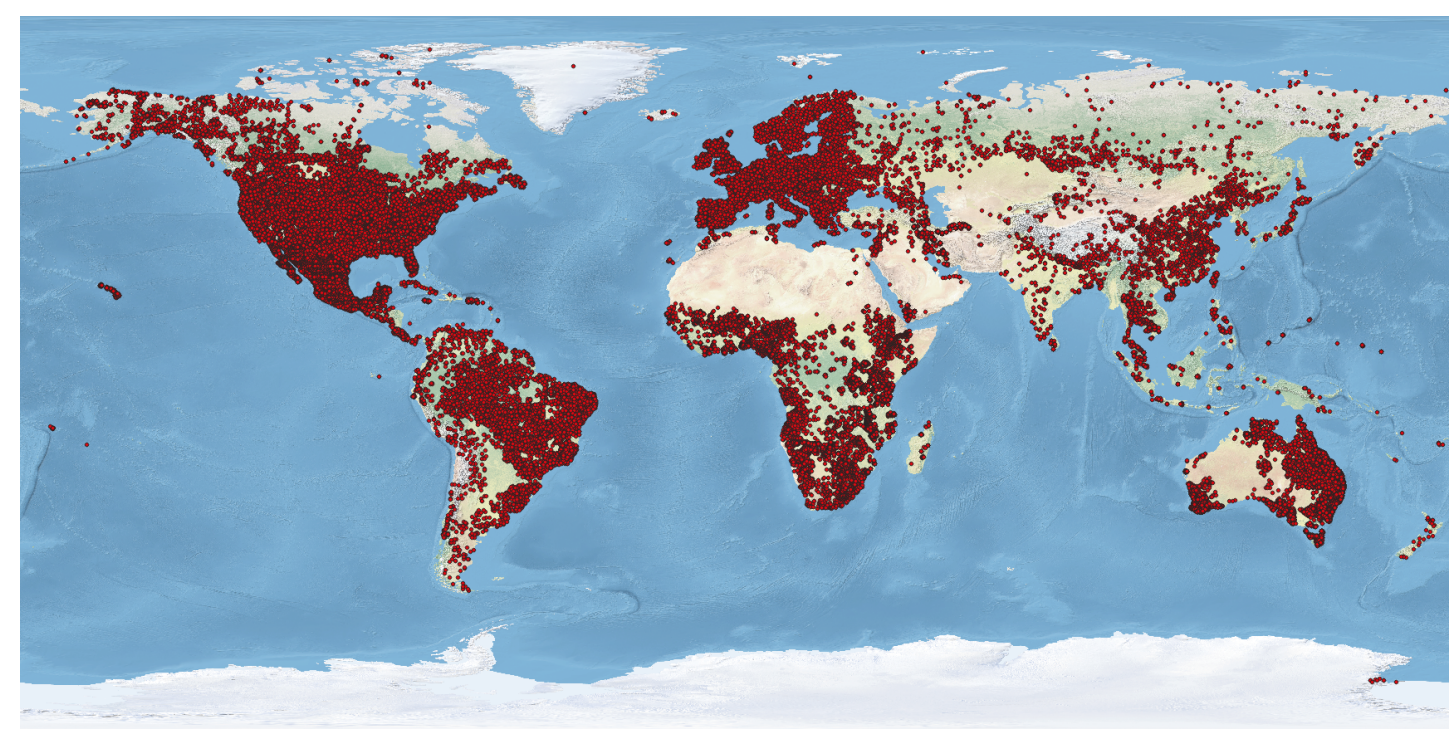

Figure 2. Location of soil profiles provided in the "September 2019" snapshot of WoSIS; see Appendix C for the number and density of profiles by country.

while others systematically sampled soil layers up to depths exceeding $20 \mathrm{~m}$.

Present gaps in the geographic distribution (Appendices $\mathrm{C}$ and D) and range of soil attribute data (Appendix A) will gradually be filled in the coming years, though this largely depends on the willingness or ability of data providers to share (some of) their data for consideration in WoSIS. For the northern boreal and Arctic region, for example, ISRIC will regularly ingest new profile data collated by the International Soil Carbon Network (ISCN, Malhotra et al., 2019). Alternatively, it should be reiterated that for some regions, such as Europe (e.g. EU LUCAS topsoil database; see Tóth et al., 2013) and the state of Victoria (Australia), there are holdings in the ISRIC repository that may only be used and standardised for SoilGrids ${ }^{\mathrm{TM}}$ applications due to licence restrictions. Consequently, the corresponding profiles $(\sim 42000)$ are neither shown in Fig. 2 nor are considered in the descriptive statistics in Appendix C.

\section{Distributing the standardised data}

Upon their standardisation, the data are distributed through ISRIC's SDI (Spatial Data Infrastructure). This web platform is based on open-source technologies and open webservices (WFS, WMS, WCS, CSW) following Open Geospatial Consortium (OGC) standards and is aimed specifically at handling soil data; our metadata are organised following standards of the International Organization for Standardization (ISO-28258, 2013) and are INSPIRE (2015) compliant. The three main components of the SDI are PostgreSQL + PostGIS, GeoServer and GeoNetwork. Visualisation and data download are done in GeoNetwork with resources from GeoServer (https://data.isric.org, last access: 12 September
2019). The third component is the PostgreSQL database, with the spatial extension PostGIS, in which WoSIS resides; the database is connected to GeoServer to permit data download from GeoNetwork. These processes are aimed at facilitating global data interoperability and citeability in compliance with FAIR principles: the data should be "findable, accessible, interoperable and reusable" (Wilkinson et al., 2016). With partners, steps are being taken towards the development of a federated and ultimately interoperable spatial soil data infrastructure (GLOSIS) through which source data are served and updated by the respective data providers and made queryable according to a common SoilML standard (OGC, 2019).

The procedure for accessing the most current set of standardised soil profile data ("wosis_latest"), either from R or QGIS using WFS, is explained in a detailed tutorial (Rossiter, 2019). This dataset is dynamic; hence, it will grow when new point data are shared and processed, additional soil attributes are considered in the WoSIS workflow, and/or when possible corrections are required. Potential errors may be reported online via a "Google group" so that they may be addressed in the dynamic version (register via: https://groups.google. com/forum/\#!forum/isric-world-soil-informationlast access: 15 January 2020).

For consistent citation purposes, we provide static snapshots of the standardised data, in a tab-separated values format, with unique DOI's (digital object identifier); as indicated, this paper describes the second WoSIS snapshot.

\section{Discussion}

The above procedures describe standardisation according to operational definitions for soil properties. Importantly, it 
should be stressed here that the ultimate, desired full harmonisation to an agreed reference method $y$, for example, " $\mathrm{pH} \mathrm{H} \mathrm{H}_{2} \mathrm{O}, 1$ : 2.5 soil / water solution" for all " $\mathrm{pH} 1: x \mathrm{H}_{2} \mathrm{O}$ " measurements, will first become feasible once the target method $(y)$ for each property has been defined and subsequently accepted by the international soil community. A next step would be to collate and develop "comparative" datasets for each soil property, i.e. sets with samples analysed according to a given reference method $\left(Y_{i}\right)$ and the corresponding national methods $\left(X_{j}\right)$ for pedotransfer function development. In practice, however, such relationships will often be soil type and region specific (see Appendix C in GlobalSoilMap, 2015). Alternatively, according to GLOSOLAN (Suvannang et al., 2018, p. 10) "comparable and useful soil information (at the global level) will only be attainable once laboratories agree to follow common standards and norms". In such a collaborative process, it will be essential to consider the end user's requirements in terms of quality and applicability of the data for their specific purposes (i.e. fitness for intended use). Over the years, many organisations have individually developed and implemented analytical methods and quality assurance systems that are well suited for their countries (e.g. Soil Survey Staff, 2014a) or regions (Orgiazzi et al., 2018) and thus, pragmatically, may not be inclined to implement the anticipated GLOSOLAN standard analytical methods.

\section{Data availability}

Snapshot "WoSIS_2019_September" is archived for long-term storage at ISRIC - World Soil Information, the World Data Centre for Soils (WDC-Soils) of the ISC (International Council for Science, formerly ICSU) World Data System (WDS). It is freely accessible at https://doi.org/10.17027/isric-wdcsoils.20190901 (Batjes et al., 2019). The zip file (154 Mb) includes a "readme first" file that describes key aspects of the dataset (see also Appendix B) with reference to the WoSIS Procedures Manual (Ribeiro et al., 2018), and the data itself in TSV format $(1.8 \mathrm{~Gb}$, decompressed) and GeoPackage format (2.2 Gb decompressed).

\section{Conclusions}

The second WoSIS snapshot provides consistent, standardised data for some 196000 profiles worldwide. However, as described, there are still important gaps in terms of geographic distribution as well as the range of soil taxonomic units and/or properties represented. These issues will be addressed in future releases, depending largely on the success of our targeted requests and searches for new data providers and/or partners worldwide.

- We will increasingly consider data derived by soil spectroscopy and emerging innovative methods. Further, long-term time series at defined locations will be sought to support space-time modelling of soil properties, such as changes in soil carbon stocks or soil salinity.

- We provide measures for geographic accuracy of the point data, as well as a first approximation for the uncertainty associated with the operationally defined analytical methods. This information may be used to assess uncertainty in digital soil mapping and earth system modelling efforts that draw on the present set of point data.

- Capacity building and cooperation among (inter)national soil institutes will be necessary to create and share ownership of the soil information newly derived from the shared data and to strengthen the necessary expertise and capacity to further develop and test the world soil information service worldwide. Such activities may be envisaged within the broader framework of the Global Soil Partnership and emerging GLOSIS system. 
Appendix A

Table A1. Coding conventions and soil property names and their description, units of measurement, inferred accuracy, and number of profiles and layers provided in the "WoSIS September 2019" snapshot. Soil properties are listed in alphabetical order using the property code.

\begin{tabular}{|c|c|c|c|c|c|c|}
\hline Code & Property & Units & Profiles & Layers & Description & $\begin{array}{l}\text { Accuracy } \\
( \pm \%)^{\mathrm{a}}\end{array}$ \\
\hline \multicolumn{7}{|l|}{ Layer data } \\
\hline BDFI33 & $\begin{array}{l}\text { Bulk density fine earth - } \\
33 \mathrm{kPa}\end{array}$ & $\mathrm{kg} \mathrm{dm}^{-3}$ & 14924 & 78215 & $\begin{array}{l}\text { Bulk density of the fine-earth } \\
\text { fraction }^{\mathrm{b}} \text {, equilibrated at } 33 \mathrm{kPa}\end{array}$ & 35 \\
\hline BDFIAD & $\begin{array}{l}\text { Bulk density fine earth - air } \\
\text { dry }\end{array}$ & $\mathrm{kg} \mathrm{dm}^{-3}$ & 1786 & 8471 & $\begin{array}{l}\text { Bulk density of the fine-earth } \\
\text { fraction, air dried }\end{array}$ & 35 \\
\hline BDFIFM & $\begin{array}{l}\text { Bulk density fine earth - } \\
\text { field moist }\end{array}$ & $\mathrm{kg} \mathrm{dm}^{-3}$ & 5279 & 14219 & $\begin{array}{l}\text { Bulk density of the fine-earth } \\
\text { fraction, field moist }\end{array}$ & 35 \\
\hline BDFIOD & $\begin{array}{l}\text { Bulk density fine earth - } \\
\text { oven dry }\end{array}$ & $\mathrm{kg} \mathrm{dm}^{-3}$ & 25124 & 122693 & $\begin{array}{l}\text { Bulk density of the fine-earth } \\
\text { fraction, oven dry }\end{array}$ & 35 \\
\hline BDWS33 & $\begin{array}{l}\text { Bulk density whole soil - } \\
33 \mathrm{kPa}\end{array}$ & $\mathrm{kg} \mathrm{dm}^{-3}$ & 26268 & 154901 & $\begin{array}{l}\text { Bulk density of the whole soil, } \\
\text { including coarse fragments, equi- } \\
\text { librated at } 33 \mathrm{kPa}\end{array}$ & 35 \\
\hline BDWSAD & $\begin{array}{l}\text { Bulk density whole soil - } \\
\text { air dry }\end{array}$ & $\mathrm{kg} \mathrm{dm}^{-3}$ & 0 & 0 & $\begin{array}{l}\text { Bulk density of the whole soil, } \\
\text { including coarse fragments, air } \\
\text { dried }\end{array}$ & 35 \\
\hline BDWSFM & $\begin{array}{l}\text { Bulk density whole soil - } \\
\text { field moist }\end{array}$ & $\mathrm{kg} \mathrm{dm}^{-3}$ & 0 & 0 & $\begin{array}{l}\text { Bulk density of the whole soil, } \\
\text { including coarse fragments, field } \\
\text { moist }\end{array}$ & 35 \\
\hline BDWSOD & $\begin{array}{l}\text { Bulk density whole soil - } \\
\text { oven dry }\end{array}$ & $\mathrm{kg} \mathrm{dm}^{-3}$ & 14588 & 75422 & $\begin{array}{l}\text { Bulk density of the whole soil, } \\
\text { including coarse fragments, oven } \\
\text { dry }\end{array}$ & 35 \\
\hline CECPH7 & $\begin{array}{l}\text { Cation exchange capacity - } \\
\text { buffered at } \mathrm{pH} 7\end{array}$ & $\operatorname{cmol}(\mathrm{c}) \mathrm{kg}^{-1}$ & 54278 & 295688 & $\begin{array}{l}\text { Capacity of the fine-earth } \\
\text { fraction to hold exchangeable } \\
\text { cations, estimated by buffering } \\
\text { the soil at "pH 7" }\end{array}$ & 20 \\
\hline СЕCPH8 & $\begin{array}{l}\text { Cation exchange capacity - } \\
\text { buffered at pH8 }\end{array}$ & $\operatorname{cmol}(\mathrm{c}) \mathrm{kg}^{-1}$ & 6422 & 23691 & $\begin{array}{l}\text { Capacity of the fine-earth } \\
\text { fraction to hold exchangeable } \\
\text { cations, estimated by buffering } \\
\text { the soil at "pH 8" }\end{array}$ & 20 \\
\hline CFGR & $\begin{array}{l}\text { Coarse fragments gravimet- } \\
\text { ric total }\end{array}$ & $\mathrm{g}$ per $100 \mathrm{~g}$ & 39527 & 203083 & $\begin{array}{l}\text { Gravimetric content of coarse } \\
\text { fragments in the whole soil }\end{array}$ & 20 \\
\hline CFVO & $\begin{array}{l}\text { Coarse fragments volumet- } \\
\text { ric total }\end{array}$ & $\mathrm{cm}^{3}$ per $100 \mathrm{~cm}^{3}$ & 45918 & 235002 & $\begin{array}{l}\text { Volumetric content of coarse } \\
\text { fragments in the whole soil }\end{array}$ & 30 \\
\hline CLAY & Clay total & $\mathrm{g}$ per $100 \mathrm{~g}$ & 141640 & 607861 & $\begin{array}{l}\text { Gravimetric content of }<x \mathrm{~mm} \\
\text { soil material in the fine-earth } \\
\text { fraction (e.g. } x=0.002 \mathrm{~mm} \text {, as } \\
\text { specified in the analytical method } \\
\text { description) } \text { b,c }\end{array}$ & 15 \\
\hline ECEC & $\begin{array}{l}\text { Effective cation exchange } \\
\text { capacity }\end{array}$ & $\operatorname{cmol}(\mathrm{c}) \mathrm{kg}^{-1}$ & 31708 & 132922 & $\begin{array}{l}\text { Capacity of the fine-earth frac- } \\
\text { tion to hold exchangeable cations } \\
\text { at the } \mathrm{pH} \text { of the soil (ECEC). } \\
\text { Conventionally approximated } \\
\text { by summation of exchangeable } \\
\text { bases }\left(\mathrm{Ca}^{2+}, \mathrm{Mg}^{2+}, \mathrm{K}^{+} \text {and }\right. \\
\left.\left.\mathrm{Na}^{+}\right) \mathrm{plus} 1 \mathrm{NCl} \text { exchangeable } \mathrm{Kcidity}^{3+} \mathrm{Al}^{3+} \text { and } \mathrm{H}^{+}\right) \text {in acidic } \\
\text { soils }\end{array}$ & 25 \\
\hline ELCO20 & $\begin{array}{l}\text { Electrical conductivity - } \\
\text { ratio } 1: 2\end{array}$ & $\mathrm{dS} \mathrm{m}^{-1}$ & 8010 & 44596 & $\begin{array}{l}\text { Ability of a } 1: 2 \text { soil-water ex- } \\
\text { tract to conduct electrical current }\end{array}$ & 10 \\
\hline
\end{tabular}


Table A1. Continued.

\begin{tabular}{|c|c|c|c|c|c|c|}
\hline Code & Property & Units & Profiles & Layers & Description & $\begin{array}{l}\text { Accuracy } \\
( \pm \%)^{\mathrm{a}}\end{array}$ \\
\hline ELCO25 & $\begin{array}{l}\text { Electrical conductivity - } \\
\text { ratio } 1: 2.5\end{array}$ & $\mathrm{dS} \mathrm{m}{ }^{-1}$ & 3313 & 15134 & $\begin{array}{l}\text { Ability of a } 1: 2.5 \text { soil-water ex- } \\
\text { tract to conduct electrical current }\end{array}$ & 10 \\
\hline ELCO50 & $\begin{array}{l}\text { Electrical conductivity - } \\
\text { ratio } 1: 5\end{array}$ & $\mathrm{dS} \mathrm{m}^{-1}$ & 23093 & 90944 & $\begin{array}{l}\text { Ability of a } 1: 5 \text { soil-water ex- } \\
\text { tract to conduct electrical current }\end{array}$ & 10 \\
\hline ELCOSP & $\begin{array}{l}\text { Electrical conductivity - } \\
\text { saturated paste }\end{array}$ & $\mathrm{dS} \mathrm{m}^{-1}$ & 19434 & 73517 & $\begin{array}{l}\text { Ability of a water-saturated soil } \\
\text { paste to conduct electrical current } \\
\left(\mathrm{EC}_{\mathrm{e}}\right)\end{array}$ & 10 \\
\hline NITKJD & Total nitrogen $(\mathrm{N})$ & $\mathrm{g} \mathrm{kg}^{-1}$ & 65356 & 216362 & $\begin{array}{l}\text { The sum of total Kjeldahl nitro- } \\
\text { gen (ammonia, organic and } \\
\text { reduced nitrogen) and nitrate- } \\
\text { nitrite }\end{array}$ & 10 \\
\hline ORGC & Organic carbon & $\mathrm{g} \mathrm{kg}^{-1}$ & 110856 & 471301 & $\begin{array}{l}\text { Gravimetric content of organic } \\
\text { carbon in the fine-earth fraction }\end{array}$ & 15 \\
\hline PHAQ & $\mathrm{pH} \mathrm{H} \mathrm{H}_{2} \mathrm{O}$ & unitless & 130986 & 613322 & $\begin{array}{l}\text { A measure of the acidity or alka- } \\
\text { linity in soils, defined as the neg- } \\
\text { ative logarithm (base } 10 \text { ) of the } \\
\text { activity of hydronium ions }\left(\mathrm{H}^{+}\right) \\
\text {in water }\end{array}$ & 0.3 \\
\hline PHCA & $\mathrm{pH} \mathrm{CaCl} 2$ & unitless & 66921 & 314230 & $\begin{array}{l}\text { A measure of the acidity or alka- } \\
\text { linity in soils, defined as the neg- } \\
\text { ative logarithm (base } 10 \text { ) of the } \\
\text { activity of hydronium ions }\left(\mathrm{H}^{+} \text {) }\right. \\
\text { in a } \mathrm{CaCl}_{2} \text { solution, as specified } \\
\text { in the analytical method descrip- } \\
\text { tions }\end{array}$ & 0.3 \\
\hline PHKC & $\mathrm{pH} \mathrm{KCl}$ & unitless & 32920 & 150447 & $\begin{array}{l}\text { A measure of the acidity or alka- } \\
\text { linity in soils, defined as the neg- } \\
\text { ative logarithm (base } 10 \text { ) of the } \\
\text { activity of hydronium ions }\left(\mathrm{H}^{+}\right) \\
\text {in a } \mathrm{KCl} \text { solution, as specified } \\
\text { in the analytical method descrip- } \\
\text { tions }\end{array}$ & 0.3 \\
\hline PHNF & $\mathrm{pH} \mathrm{NaF}$ & unitless & 4978 & 25448 & $\begin{array}{l}\text { A measure of the acidity or alka- } \\
\text { linity in soils, defined as the neg- } \\
\text { ative logarithm (base } 10 \text { ) of the } \\
\text { activity of hydronium ions }\left(\mathrm{H}^{+}\right) \\
\text {in a } \mathrm{NaF} \text { solution, as specified } \\
\text { in the analytical method descrip- } \\
\text { tions }\end{array}$ & 0.3 \\
\hline PHPBYI & Phosphorus (P) - Bray-I & $\mathrm{mg} \mathrm{kg}^{-1}$ & 10735 & 40486 & $\begin{array}{l}\text { Measured according to the Bray- } \\
\mathrm{I} \text { method, a combination of } \mathrm{HCl} \\
\text { and } \mathrm{NH}_{4} \mathrm{~F} \text { to remove easily acid } \\
\text { soluble } \mathrm{P} \text { forms, largely } \mathrm{Al} \text { and } \\
\text { Fe phosphates (for acid soils) }\end{array}$ & 40 \\
\hline PHPMH3 & $\begin{array}{l}\text { Phosphorus }(\mathrm{P}) \text { - Mehlich- } \\
3\end{array}$ & $\mathrm{mg} \mathrm{kg}^{-1}$ & 1446 & 7242 & $\begin{array}{l}\text { Measured according to the } \\
\text { Mehlich-3 extractant, a combi- } \\
\text { nation of acids (acetic [HOAc] } \\
\text { and nitric }\left[\mathrm{HNO}_{3}\right] \text { ), salts (am- } \\
\text { monium fluoride }\left[\mathrm{NH}_{4} \mathrm{~F}\right] \text { and } \\
\text { ammonium nitrate }\left[\mathrm{NH}_{4} \mathrm{NO}_{3}\right] \text { ), } \\
\text { and the chelating agent ethylene- } \\
\text { diaminetetraacetic acid (EDTA); } \\
\text { considered suitable for removing } \\
\mathrm{P} \text { and other elements in acid and } \\
\text { neutral soils }\end{array}$ & 25 \\
\hline
\end{tabular}


Table A1. Continued.

\begin{tabular}{|c|c|c|c|c|c|c|}
\hline Code & Property & Units & Profiles & Layers & Description & $\begin{array}{l}\text { Accuracy } \\
( \pm \%)^{\mathrm{a}}\end{array}$ \\
\hline PHPOLS & Phosphorus (P) - Olsen & $\mathrm{mg} \mathrm{kg}^{-1}$ & 2162 & 8434 & $\begin{array}{l}\text { Measured according to the Olsen } \\
\mathrm{P} \text { method: } 0.5 \mathrm{M} \text { sodium bicar- } \\
\text { bonate }\left(\mathrm{NaHCO}_{3}\right) \text { solution at a } \\
\mathrm{pH} \text { of } 8.5 \text { to extract } \mathrm{P} \text { from } \\
\text { calcareous, alkaline and neutral } \\
\text { soils }\end{array}$ & 25 \\
\hline PHPRTN & Phosphorus $(\mathrm{P})$ - retention & $\mathrm{mg} \mathrm{kg}^{-1}$ & 4636 & 23917 & $\begin{array}{l}\text { Retention measured according to } \\
\text { the New Zealand method }\end{array}$ & 20 \\
\hline РHPTOT & Phosphorus $(\mathrm{P})$ - total & $\mathrm{mg} \mathrm{kg}^{-1}$ & 4022 & 12976 & $\begin{array}{l}\text { Determined with a very strong } \\
\text { acid (aqua regia and sulfuric acid } \\
\text { or nitric acid) }\end{array}$ & 15 \\
\hline PHPWSL & $\begin{array}{l}\text { Phosphorus }(\mathrm{P}) \text { - water sol- } \\
\text { uble }\end{array}$ & $\mathrm{mg} \mathrm{kg}^{-1}$ & 283 & 1242 & $\begin{array}{l}\text { Measured in } 1: x \text { soil:water solu- } \\
\text { tion (mainly determines } \mathrm{P} \text { in dis- } \\
\text { solved forms) }\end{array}$ & 15 \\
\hline SAND & Sand total & $\mathrm{g}$ per $100 \mathrm{~g}$ & 105547 & 491810 & $\begin{array}{l}\text { The } y \text { to } z \mathrm{~mm} \text { fraction of the } \\
\text { fine-earth fraction and } z \text { upper } \\
\text { limit, as specified in the analyt- } \\
\text { ical method description for the } \\
\text { sand fraction (e.g. } y=0.05 \mathrm{~mm} \\
\text { to } z=2 \mathrm{~mm})^{\mathrm{c}}\end{array}$ & 15 \\
\hline SILT & Silt total & $\mathrm{g}$ per $100 \mathrm{~g}$ & 133938 & 575913 & $\begin{array}{l}x \text { to } y \mathrm{~mm} \text { fraction of the fine- } \\
\text { earth fraction and } x \text { upper limit, } \\
\text { as specified in the analytical } \\
\text { method description for the clay } \\
\text { fraction }(\mathrm{e} . \mathrm{g} . \quad x=0.002 \mathrm{~mm} \text { to } \\
y=0.05 \mathrm{~mm})^{\mathrm{c}}\end{array}$ & 15 \\
\hline TCEQ & $\begin{array}{l}\text { Calcium carbonate equiva- } \\
\text { lent total }\end{array}$ & $\mathrm{g} \mathrm{kg}^{-1}$ & 51991 & 222242 & $\begin{array}{l}\text { The content of carbonate in a lim- } \\
\text { ing material or calcareous soil } \\
\text { calculated as if all of the car- } \\
\text { bonate is in the form of } \mathrm{CaCO}_{3} \\
\text { (in the fine-earth fraction), also } \\
\text { known as inorganic carbon }\end{array}$ & 10 \\
\hline TOTC & Total carbon $(\mathrm{C})$ & $\mathrm{g} \mathrm{kg}^{-1}$ & 32662 & 109953 & $\begin{array}{l}\text { Gravimetric content of organic } \\
\text { carbon and inorganic carbon in } \\
\text { the fine-earth fraction }\end{array}$ & 10 \\
\hline WG0006 & $\begin{array}{l}\text { Water retention gravimetric } \\
-6 \mathrm{kPa}\end{array}$ & $\mathrm{g}$ per $100 \mathrm{~g}$ & 863 & 4264 & $\begin{array}{l}\text { Soil moisture content by weight, } \\
\text { at tension } 6 \mathrm{kPa}(\mathrm{pF} 1.8)\end{array}$ & 20 \\
\hline WG0010 & $\begin{array}{l}\text { Water retention gravimetric } \\
-10 \mathrm{kPa}\end{array}$ & $\mathrm{g}$ per $100 \mathrm{~g}$ & 3357 & 14739 & $\begin{array}{l}\text { Soil moisture content by weight, } \\
\text { at tension } 10 \mathrm{kPa}(\mathrm{pF} 2.0)\end{array}$ & 20 \\
\hline WG0033 & $\begin{array}{l}\text { Water retention gravimetric } \\
-33 \mathrm{kPa}\end{array}$ & $\mathrm{g}$ per $100 \mathrm{~g}$ & 21116 & 96354 & $\begin{array}{l}\text { Soil moisture content by weight, } \\
\text { at tension } 33 \mathrm{kPa}(\mathrm{pF} 2.5)\end{array}$ & 20 \\
\hline WG0100 & $\begin{array}{l}\text { Water retention gravimetric } \\
-100 \mathrm{kPa}\end{array}$ & $\mathrm{g}$ per $100 \mathrm{~g}$ & 696 & 3762 & $\begin{array}{l}\text { Soil moisture content by weight, } \\
\text { at tension } 100 \mathrm{kPa}(\mathrm{pF} 3.0)\end{array}$ & 20 \\
\hline WG0200 & $\begin{array}{l}\text { Water retention gravimetric } \\
-200 \mathrm{kPa}\end{array}$ & $\mathrm{g}$ per $100 \mathrm{~g}$ & 4418 & 28239 & $\begin{array}{l}\text { Soil moisture content by weight, } \\
\text { at tension } 200 \mathrm{kPa}(\mathrm{pF} 3.3)\end{array}$ & 20 \\
\hline WG0500 & $\begin{array}{l}\text { Water retention gravimetric } \\
-500 \mathrm{kPa}\end{array}$ & $\mathrm{g}$ per $100 \mathrm{~g}$ & 344 & 1716 & $\begin{array}{l}\text { Soil moisture content by weight, } \\
\text { at tension } 500 \mathrm{kPa}(\mathrm{pF} 3.7)\end{array}$ & 20 \\
\hline WG1500 & $\begin{array}{l}\text { Water retention gravimetric } \\
-1500 \mathrm{kPa}\end{array}$ & $\mathrm{g}$ per $100 \mathrm{~g}$ & 34365 & 187176 & $\begin{array}{l}\text { Soil moisture content by weight, } \\
\text { at tension } 1500 \mathrm{kPa}(\mathrm{pF} 4.2)\end{array}$ & 20 \\
\hline WV0006 & $\begin{array}{l}\text { Water retention volumetric } \\
-6 \mathrm{kPa}\end{array}$ & $\mathrm{cm}^{3}$ per $100 \mathrm{~cm}^{3}$ & 9 & 26 & $\begin{array}{l}\text { Soil moisture content by volume, } \\
\text { at tension } 6 \mathrm{kPa}(\mathrm{pF} 1.8)\end{array}$ & 20 \\
\hline WV0010 & $\begin{array}{l}\text { Water retention volumetric } \\
-10 \mathrm{kPa}\end{array}$ & $\mathrm{cm}^{3}$ per $100 \mathrm{~cm}^{3}$ & 1469 & 5434 & $\begin{array}{l}\text { Soil moisture content by volume, } \\
\text { at tension } 10 \mathrm{kPa}(\mathrm{pF} 2.0)\end{array}$ & 20 \\
\hline
\end{tabular}


Table A1. Continued.

\begin{tabular}{|c|c|c|c|c|c|c|}
\hline Code & Property & Units & Profiles & Layers & Description & $\begin{array}{l}\text { Accuracy } \\
\quad( \pm \%)^{\mathrm{a}}\end{array}$ \\
\hline WV0033 & $\begin{array}{l}\text { Water retention volumetric } \\
-33 \mathrm{kPa}\end{array}$ & $\mathrm{cm}^{3}$ per $100 \mathrm{~cm}^{3}$ & 5987 & 17801 & $\begin{array}{l}\text { Soil moisture content by volume, } \\
\text { at tension } 33 \mathrm{kPa}(\mathrm{pF} 2.5)\end{array}$ & 20 \\
\hline WV0100 & $\begin{array}{l}\text { Water retention volumetric } \\
-100 \mathrm{kPa}\end{array}$ & $\mathrm{cm}^{3}$ per $100 \mathrm{~cm}^{3}$ & 747 & 2559 & $\begin{array}{l}\text { Soil moisture content by volume, } \\
\text { at tension } 100 \mathrm{kPa}(\mathrm{pF} 3.0)\end{array}$ & 20 \\
\hline WV0200 & $\begin{array}{l}\text { Water retention volumetric } \\
-200 \mathrm{kPa}\end{array}$ & $\mathrm{cm}^{3}$ per $100 \mathrm{~cm}^{3}$ & 3 & 9 & $\begin{array}{l}\text { Soil moisture content by volume, } \\
\text { at tension } 200 \mathrm{kPa}(\mathrm{pF} 3.3)\end{array}$ & 20 \\
\hline WV0500 & $\begin{array}{l}\text { Water retention volumetric } \\
-500 \mathrm{kPa}\end{array}$ & $\mathrm{cm}^{3}$ per $100 \mathrm{~cm}^{3}$ & 703 & 1763 & $\begin{array}{l}\text { Soil moisture content by volume, } \\
\text { at tension } 500 \mathrm{kPa}(\mathrm{pF} 3.7)\end{array}$ & 20 \\
\hline WV1500 & $\begin{array}{l}\text { Water retention volumetric } \\
-1500 \mathrm{kPa}\end{array}$ & $\mathrm{cm}^{3}$ per $100 \mathrm{~cm}^{3}$ & 6149 & 17542 & $\begin{array}{l}\text { Soil moisture content by volume, } \\
\text { at tension } 1500 \mathrm{kPa}(\mathrm{pF} 4.2)\end{array}$ & 20 \\
\hline \multicolumn{7}{|l|}{ Site data } \\
\hline CSTX & $\begin{array}{l}\text { Soil classification Soil tax- } \\
\text { onomy }\end{array}$ & classes & 21314 & $\mathrm{n} / \mathrm{a}$ & $\begin{array}{l}\text { Classification of the soil profile, } \\
\text { according to the specified edition } \\
\text { (year) of USDA Soil Taxonomy, } \\
\text { up to subgroup level when avail- } \\
\text { able }\end{array}$ & - \\
\hline CWRB & Soil classification WRB & classes & 26664 & $\mathrm{n} / \mathrm{a}$ & $\begin{array}{l}\text { Classification of the soil profile, } \\
\text { according to the specified edition } \\
\text { (year) of the World Reference } \\
\text { Base for Soil Resources (WRB), } \\
\text { up to qualifier level when avail- } \\
\text { able }\end{array}$ & - \\
\hline CFAO & Soil classification FAO & classes & 23890 & $\mathrm{n} / \mathrm{a}$ & $\begin{array}{l}\text { Classification of the soil profile, } \\
\text { according to the specified edition } \\
\text { (year) of the FAO-Unesco Leg- } \\
\text { end, up to soil unit level when } \\
\text { available }\end{array}$ & - \\
\hline DSDS & Depth of soil - sampled & $\mathrm{cm}$ & 196381 & $\mathrm{n} / \mathrm{a}$ & $\begin{array}{l}\text { Maximum depth of soil described } \\
\text { and sampled (calculated) }\end{array}$ & - \\
\hline HODS & Horizon designation & - & 80849 & 396522 & $\begin{array}{l}\text { Horizon designation as provided } \\
\text { in the source database }\end{array}$ & \\
\hline $\begin{array}{l}\text { a Inferred accu } \\
\text { al. (2018), Kalr } \\
\text { approximations } \\
\text { b Generally, th } \\
\text { scheme). This } 1 \\
\text { is important (se } \\
\text { d Where availa }\end{array}$ & $\begin{array}{l}\text { acy (or uncertainty), rounded to the nea } \\
\text { and Maynard (1991), Rayment and Ly } \\
\text { that will be fine-tuned once more speci } \\
\text { fine-earth fraction is defined as being } \\
\text { as been indicated in the file "wosis_201 } \\
\text { "sample pretreatment" in string "xxxx } \\
\text { le, the "cleaned" (original) layer and ho }\end{array}$ & $\begin{array}{l}\text { est } 5 \% \text {, unless otherwise } \\
\text { ons (2011), Rossel and M } \\
\text { ic results of laboratory pr } \\
2 \mathrm{~mm} \text {. Alternatively, an } \\
907 \text { layers_chemical.tsv" } \\
\text { _method" in Appendix B) } \\
\text { rizon designation is provi }\end{array}$ & $\begin{array}{l}\text { dicated (i.e. } \\
\text { 3ratney (199 } \\
\text { iciency tests, } \\
\text { per limit of } 1 \\
\text { nd "wosis_2 } \\
\text { c Provided or } \\
\text { ed for genera }\end{array}$ & $\begin{array}{l}\text { nits for soil p } \\
\text {, van Reeuwi } \\
\text { rom national } \\
\text { mm was used } \\
\text { 1907_layer_p } \\
\text { y when the st }\end{array}$ & $\begin{array}{l}\text { H), as derived from the following sources: Al- } \\
\text { k (1983), WEPAL (2019). These figures are fi } \\
\text { ooil Quality Management systems, become av } \\
\text { n the former Soviet Union and its satellite stat } \\
\text { nysicals.tsv" for those soil properties where th } \\
\text { m of clay, silt and sand fraction is } \geq 90 \% \text { and } \\
\text { nese codes have not been standardised as they }\end{array}$ & $\begin{array}{l}\text { lammary et } \\
\mathrm{t} \\
\text { lable. } \\
\text { s (Katchynsky } \\
\text { differentiation } \\
100 \% \text {. } \\
\text { ary widely } \\
\text { e flagged all } \\
\text { al., 2018, p. 24, }\end{array}$ \\
\hline
\end{tabular}


Appendix B: Structure of the "September 2019"

WoSIS snapshot

This Appendix describes the structure of the data files presented in the "September 2019" WoSIS snapshot:

- wosis_201909_attributes.tsv,

- wosis_201909_profiles.tsv,

- wosis_201909_layers_chemical.tsv,

- wosis_201909_layer_physicals.tsv.

wosis_201909_attributes.tsv. This file lists the four to six letter codes for each attribute, whether the attribute is a site or horizon property, the unit of measurement, the number of profiles and layers represented in the snapshot, and a brief description of each attribute, as well as the inferred uncertainty for each property (Appendix A).

wosis_201909_profiles.tsv. This file contains the unique profile ID (i.e. primary key), the source of the data, country ISO code and name, accuracy of geographical coordinates, latitude and longitude (WGS 1984), point geometry of the location of the profile, and the maximum depth of soil described and sampled, as well as information on the soil classification system and edition (Table B1). Depending on the soil classification system used, the number of fields will vary. For example, for the World Soil Reference Base (WRB) system these are as follows: publication_year (i.e. version), reference_soil_group_code, reference_soil_group_name, and the name(s) of the prefix (primary) qualifier(s) and suffix (supplementary) qualifier(s). The terms principal qualifier and supplementary qualifier are currently used (IUSS Working Group WRB, 2015); earlier WRB versions used prefix and suffix for this (e.g. IUSS Working Group WRB, 2006). Alternatively, for USDA Soil Taxonomy, the version (year), order, suborder, great group and subgroup can be accommodated (Soil Survey Staff, 2014b). Inherently, the number of records filled will vary between (and within) the various source databases.

wosis_201909_layer_chemical.tsv and wosis_201909_layer_physical.tsv. Data for the various layers (or horizons) are presented in two separate files in view of their size (i.e. one for the chemical and one for the physical soil properties). The file structure is described in Table B1.

Format. All fields in the above files are delimited by tab, with double quotation marks as text delimiters. File coding is according to the UTF-8 unicode transformation format.

Using the data. The above TSV files can easily be imported into an SQL database or statistical software such as R, after which they may be joined using the unique profile_id. Guidelines for handling and querying the data are provided in the WoSIS Procedures Manual (Ribeiro et al., 2018, pp. 4548); see also the detailed tutorial by Rossiter (2019). 
Table B1. List of properties described in file wosis_201909_profiles.tsv, wosis_201909_layers_chemical.tsv and wosis_201909_layer_physicals.tsv.

\begin{tabular}{|c|c|}
\hline File name/Property & Description \\
\hline wosis_201909_profiles.tsv & This file specifies the main characteristics of a soil profile \\
\hline profile_id & Primary key \\
\hline dataset_id & Identifier for source dataset \\
\hline country_id & ISO code for country name \\
\hline country_name & Country name (in English) \\
\hline geom_accuracy & $\begin{array}{l}\text { Accuracy of the geographical coordinates in degrees, e.g if degrees, minutes and seconds } \\
\text { are provided in the source then geom_accuracy is set at } 0.01 \text {, if seconds are missing it is set } \\
\text { at } 0.1 \text {, and if seconds and minutes are missing it is set at } 1\end{array}$ \\
\hline latitude & Latitude in degrees (WGS84) \\
\hline longitude & Longitude in degrees (WGS84) \\
\hline dsds & Maximum depth of soil described and sampled (calculated) \\
\hline cfao_version & Version of FAO legend (e.g. 1974 or 1988) \\
\hline cfao_major_group_code & Code for major group (in given version of the legend) \\
\hline cfao_major_group & Name of major group \\
\hline cfao_soil_unit_code & Code for soil unit \\
\hline cfao_soil_unit & Name of soil unit \\
\hline cwrb_version & Version of World Reference Base for Soil Resources \\
\hline cwrb_reference_soil_group_code & Code for WRB group (in given version of WRB) \\
\hline cwrb_reference_soil_group & Full name for reference soil group \\
\hline cwrb_prefix_qualifier & Name for prefix (e.g. for WRB1988) or principal qualifier (e.g. for WRB2015) \\
\hline cwrb_suffix_qualifier & Name for suffix (e.g. for WRB1988) or supplementary qualifier (e.g. for WRB2015) \\
\hline cstx_version & Version of USDA Soil Taxonomy (UST) \\
\hline cstx_order_name & Name of UST order \\
\hline cstx_suborder & Name of UST suborder \\
\hline cstx_great_group & Name of UST great group \\
\hline cstx_subgroup & Name of UST subgroup \\
\hline wosis_201909_layer_chemical.tsv and & The layer (horizon) data are presented in two separate files in view of their size, one for the \\
\hline $\begin{array}{l}\text { wosis_201909_layer_physical.tsv } \\
\text { profile_id }\end{array}$ & $\begin{array}{l}\text { chemical and one for the physical soil properties. Both files have the same structure. } \\
\text { Identifier for profile, foreign key to 'wosis_201909_profiles' }\end{array}$ \\
\hline profile_layer_id & Unique identifier for layer for given profile (primary key) \\
\hline upper_depth & Upper depth of layer (or horizon; $\mathrm{cm}$ ) \\
\hline lower_depth & Lower depth of layer $(\mathrm{cm})$ \\
\hline layer_name & Name of the horizon, as provided in the source data \\
\hline litter & Flag (Boolean) indicating whether this is considered a surficial litter layer \\
\hline xxxx_value* & $\begin{array}{l}\text { Array listing all measurement values for soil property "xxxx" (e.g. BDFI33 or PHAQ) for } \\
\text { the given layer. In some cases, more than one observation is reported for a given horizon } \\
\text { (layer) in the source, for example, four values for TOTC: }\{1: 5.4,2: 8.2,3: 6.3,4: 7.7\}\end{array}$ \\
\hline xxxx_value_avg & Average, for above (it is recommended to use this value for "routine" modelling) \\
\hline xxxx_method & $\begin{array}{l}\text { Array listing the method descriptions for each value. The nature of this array varies with } \\
\text { the soil property under consideration, as described in the option tables for each analytical } \\
\text { method. For example, in the case of electrical conductivity (ELCO), the method is described } \\
\text { using sample pretreatment (e.g. sieved over } 2 \text { mm size, solution (e.g. water), ratio (e.g., } \\
1: 5 \text { ), and ratio base (e.g. weight/volume). Details for each method are provided in the } \\
\text { WoSIS Procedures Manual (Appendices D, E, and F in Ribeiro et al., 2018). }\end{array}$ \\
\hline xxxx_date & Array listing the date of observation for each value \\
\hline xxxx_dataset_id & Abbreviation for source data set (e.g. WD-ISCN) \\
\hline xxxx_profile_code & Code for given profile in the source dataset \\
\hline xxxx_license & Licence for given data, as indicated by the data provider (e.g. CC-BY). \\
\hline$(\ldots)$ & The above "xxxx" fields are repeated for each soil property considered in Table A1. \\
\hline
\end{tabular}

* Name of attribute ("xxxx") as defined under "code" in file wosis_201909_attributes.tsv. 


\section{Appendix C}

Table C1. Number of profiles by country and continent.

\begin{tabular}{|c|c|c|c|c|c|}
\hline Continent & Country name & $\begin{array}{l}\text { ISO } \\
\text { code }\end{array}$ & $\begin{array}{l}\text { No. of } \\
\text { profiles }\end{array}$ & $\begin{array}{r}\text { Area } \\
\left(\mathrm{km}^{2}\right)\end{array}$ & $\begin{array}{l}\text { Profile density } \\
\left(\text { per } 1000 \mathrm{~km}^{2}\right)\end{array}$ \\
\hline \multirow[t]{45}{*}{ Africa } & Algeria & $\mathrm{DZ}$ & 10 & 2308647 & 0.004 \\
\hline & Angola & $\mathrm{AO}$ & 1169 & 1246690 & 0.938 \\
\hline & Benin & BJ & 744 & 115247 & 6.456 \\
\hline & Botswana & BW & 994 & 578247 & 1.719 \\
\hline & Burkina Faso & $\mathrm{BF}$ & 2023 & 273281 & 7.403 \\
\hline & Burundi & BI & 1063 & 26857 & 39.58 \\
\hline & Cameroon & $\mathrm{CM}$ & 1306 & 465363 & 2.806 \\
\hline & Central African Republic & $\mathrm{CF}$ & 88 & 619591 & 0.142 \\
\hline & Chad & TD & 7 & 1265392 & 0.006 \\
\hline & Côte d'Ivoire & CI & 255 & 321762 & 0.793 \\
\hline & Democratic Republic of the Congo & $\mathrm{CD}$ & 380 & 2329162 & 0.163 \\
\hline & Egypt & EG & 26 & 982161 & 0.026 \\
\hline & Ethiopia & ET & 1712 & 1129314 & 1.516 \\
\hline & Gabon & GA & 47 & 264022 & 0.178 \\
\hline & Ghana & GH & 432 & 238842 & 1.809 \\
\hline & Guinea & GN & 128 & 243023 & 0.527 \\
\hline & Guinea-Bissau & GW & 18 & 30740 & 0.586 \\
\hline & Kenya & $\mathrm{KE}$ & 1601 & 582342 & 2.749 \\
\hline & Lesotho & LS & 33 & 30453 & 1.084 \\
\hline & Liberia & LR & 50 & 96103 & 0.52 \\
\hline & Libya & LY & 14 & 1620583 & 0.009 \\
\hline & Madagascar & MG & 131 & 588834 & 0.222 \\
\hline & Malawi & MW & 3049 & 118715 & 25.683 \\
\hline & Mali & ML & 884 & 1251471 & 0.706 \\
\hline & Mauritania & MR & 13 & 1038527 & 0.013 \\
\hline & Morocco & MA & 113 & 414030 & 0.273 \\
\hline & Mozambique & $\mathrm{MZ}$ & 566 & 787305 & 0.719 \\
\hline & Namibia & NA & 1462 & 823989 & 1.774 \\
\hline & Niger & $\mathrm{NE}$ & 520 & 1182602 & 0.44 \\
\hline & Nigeria & NG & 1402 & 908978 & 1.542 \\
\hline & Republic of the Congo & $\mathrm{CG}$ & 71 & 340599 & 0.208 \\
\hline & Rwanda & RW & 2007 & 25388 & 79.052 \\
\hline & Senegal & $\mathrm{SN}$ & 312 & 196200 & 1.59 \\
\hline & Sierra Leone & SL & 12 & 72281 & 0.166 \\
\hline & Somalia & SO & 245 & 632562 & 0.387 \\
\hline & South Africa & $\mathrm{ZA}$ & 874 & 1220127 & 0.716 \\
\hline & South Sudan & SS & 82 & 629821 & 0.13 \\
\hline & Sudan & SD & 130 & 1843196 & 0.071 \\
\hline & Swaziland & SZ & 14 & 17290 & 0.81 \\
\hline & Togo & TG & 9 & 56767 & 0.159 \\
\hline & Tunisia & $\mathrm{TN}$ & 60 & 155148 & 0.387 \\
\hline & Uganda & $\mathrm{UG}$ & 683 & 241495 & 2.828 \\
\hline & Tanzania & $\mathrm{TZ}$ & 1915 & 939588 & 2.038 \\
\hline & Zambia & $\mathrm{ZM}$ & 601 & 751063 & 0.8 \\
\hline & Zimbabwe & $\mathrm{ZW}$ & 413 & 390648 & 1.057 \\
\hline Antarctica & Antarctica & AQ & 9 & 12537967 & 0.001 \\
\hline \multirow[t]{3}{*}{ Asia } & Afghanistan & $\mathrm{AF}$ & 19 & 641827 & 0.03 \\
\hline & Armenia & $\mathrm{AM}$ & 7 & 29624 & 0.236 \\
\hline & Arunachal Pradesh & $*$ & 2 & 67965 & 0.029 \\
\hline
\end{tabular}


Table C1. Continued.

\begin{tabular}{|c|c|c|c|c|c|}
\hline Continent & Country name & $\begin{array}{l}\text { ISO } \\
\text { code }\end{array}$ & $\begin{array}{l}\text { No. of } \\
\text { profiles }\end{array}$ & $\begin{array}{r}\text { Area } \\
\left(\mathrm{km}^{2}\right)\end{array}$ & $\begin{array}{l}\text { Profile density } \\
\left(\text { per } 1000 \mathrm{~km}^{2}\right)\end{array}$ \\
\hline & Azerbaijan & $\mathrm{AZ}$ & 24 & 164780 & 0.146 \\
\hline & Bahrain & $\mathrm{BH}$ & 2 & 673 & 2.97 \\
\hline & Bangladesh & $\mathrm{BD}$ & 207 & 139825 & 1.48 \\
\hline & Bhutan & BT & 85 & 37674 & 2.256 \\
\hline & Cambodia & $\mathrm{KH}$ & 409 & 181424 & 2.254 \\
\hline & China & $\mathrm{CN}$ & 1648 & 9345214 & 0.176 \\
\hline & Cyprus & $\mathrm{CY}$ & 12 & 9249 & 1.297 \\
\hline & Georgia & GE & 17 & 69785 & 0.244 \\
\hline & Hong Kong & HK & 2 & 1081 & 1.851 \\
\hline & India & IN & 199 & 2961118 & 0.067 \\
\hline & Indonesia & ID & 180 & 1888620 & 0.095 \\
\hline & Iran & IR & 2010 & 1677319 & 1.198 \\
\hline & Iraq & IQ & 14 & 435864 & 0.032 \\
\hline & Israel & IL & 17 & 20720 & 0.82 \\
\hline & Jammu and Kashmir & $*$ & 4 & 186035 & 0.022 \\
\hline & Japan & $\mathrm{JP}$ & 198 & 373651 & 0.53 \\
\hline & Jordan & $\mathrm{JO}$ & 47 & 89063 & 0.528 \\
\hline & Kazakhstan & $\mathrm{KZ}$ & 12 & 2841103 & 0.004 \\
\hline & Kuwait & KW & 1 & 17392 & 0.057 \\
\hline & Kyrgyzstan & KG & 1 & 199188 & 0.005 \\
\hline & Lao & LA & 20 & 230380 & 0.087 \\
\hline & Lebanon & LB & 10 & 10136 & 0.987 \\
\hline & Malaysia & MY & 157 & 329775 & 0.476 \\
\hline & Mongolia & $\mathrm{MN}$ & 9 & 1564529 & 0.006 \\
\hline & Nepal & $\mathrm{NP}$ & 142 & 147437 & 0.963 \\
\hline & Oman & $\mathrm{OM}$ & 9 & 308335 & 0.029 \\
\hline & Pakistan & PK & 45 & 788439 & 0.057 \\
\hline & Philippines & PH & 81 & 296031 & 0.274 \\
\hline & South Korea & $\mathrm{KR}$ & 23 & 99124 & 0.232 \\
\hline & Saudi Arabia & SA & 7 & 1925621 & 0.004 \\
\hline & Singapore & SG & 1 & 594 & 1.683 \\
\hline & Sri Lanka & LK & 72 & 66173 & 1.088 \\
\hline & State of Palestine & PS* & 18 & 6225 & 2.892 \\
\hline & Syria & SY & 68 & 188128 & 0.361 \\
\hline & Taiwan & TW & 35 & 36127 & 0.969 \\
\hline & Tajikistan & $\mathrm{TJ}$ & 5 & 142004 & 0.035 \\
\hline & Thailand & $\mathrm{TH}$ & 482 & 515417 & 0.935 \\
\hline & Turkey & TR & 69 & 781229 & 0.088 \\
\hline & United Arab Emirates & $\mathrm{AE}$ & 12 & 71079 & 0.169 \\
\hline & Uzbekistan & $\mathrm{UZ}$ & 9 & 449620 & 0.02 \\
\hline & Viet Nam & $\mathrm{VN}$ & 29 & 327575 & 0.089 \\
\hline & Yemen & YE & 284 & 453596 & 0.626 \\
\hline \multirow[t]{13}{*}{ Europe } & Albania & AL & 97 & 28682 & 3.382 \\
\hline & Austria & AT & 128 & 83964 & 1.524 \\
\hline & Belarus & BY & 92 & 207581 & 0.443 \\
\hline & Belgium & $\mathrm{BE}$ & 7009 & 30669 & 228.536 \\
\hline & Bosnia and Herzegovina & BA & 32 & 51145 & 0.626 \\
\hline & Bulgaria & BG & 136 & 111300 & 1.222 \\
\hline & Croatia & HR & 78 & 56589 & 1.378 \\
\hline & Czech Republic & $\mathrm{CZ}$ & 664 & 78845 & 8.422 \\
\hline & Denmark & DK & 74 & 44458 & 1.664 \\
\hline & Estonia & $\mathrm{EE}$ & 242 & 45441 & 5.326 \\
\hline & Finland & FI & 444 & 336892 & 1.318 \\
\hline & France & FR & 1037 & 548785 & 1.89 \\
\hline & Germany & DE & 4345 & 357227 & 12.163 \\
\hline
\end{tabular}


Table C1. Continued.

\begin{tabular}{|c|c|c|c|c|c|}
\hline Continent & Country name & $\begin{array}{l}\text { ISO } \\
\text { code }\end{array}$ & $\begin{array}{l}\text { No. of } \\
\text { profiles }\end{array}$ & $\begin{array}{r}\text { Area } \\
\left(\mathrm{km}^{2}\right)\end{array}$ & $\begin{array}{l}\text { Profile density } \\
\left(\text { per } 1000 \mathrm{~km}^{2}\right)\end{array}$ \\
\hline & Greece & GR & 370 & 132549 & 2.791 \\
\hline & Hungary & $\mathrm{HU}$ & 1420 & 93119 & 15.249 \\
\hline & Iceland & IS & 11 & 102566 & 0.107 \\
\hline & Ireland & $\mathrm{IE}$ & 125 & 69809 & 1.791 \\
\hline & Italy & IT & 575 & 301651 & 1.906 \\
\hline & Latvia & LV & 102 & 64563 & 1.58 \\
\hline & Lithuania & $\mathrm{LT}$ & 127 & 64943 & 1.956 \\
\hline & Luxembourg & LU & 141 & 2621 & 53.802 \\
\hline & Montenegro & ME & 12 & 13776 & 0.871 \\
\hline & Netherlands & NL & 320 & 35203 & 9.09 \\
\hline & North Macedonia & MK & 20 & 25424 & 0.787 \\
\hline & Norway & NO & 507 & 324257 & 1.564 \\
\hline & Poland & PL & 618 & 311961 & 1.981 \\
\hline & Portugal & $\mathrm{PT}$ & 460 & 91876 & 5.007 \\
\hline & Moldova & MD & 35 & 33798 & 1.036 \\
\hline & Romania & RO & 104 & 238118 & 0.437 \\
\hline & Russian Federation & RU & 1410 & 16998830 & 0.083 \\
\hline & Serbia & RS & 69 & 88478 & 0.78 \\
\hline & Slovakia & SK & 161 & 49072 & 3.281 \\
\hline & Slovenia & SI & 67 & 20320 & 3.297 \\
\hline & Spain & ES & 905 & 505752 & 1.789 \\
\hline & Svalbard and Jan Mayen Islands & SJ & 4 & 63464 & 0.063 \\
\hline & Sweden & SE & 583 & 449212 & 1.298 \\
\hline & Switzerland & $\mathrm{CH}$ & 10943 & 41257 & 265.238 \\
\hline & Ukraine & UA & 409 & 600526 & 0.681 \\
\hline & United Kingdom & GB & 1435 & 244308 & 5.874 \\
\hline \multirow[t]{20}{*}{ North America } & Barbados & $\mathrm{BB}$ & 3 & 433 & 6.928 \\
\hline & Belize & $\mathrm{BZ}$ & 29 & 21764 & 1.332 \\
\hline & Canada & $\mathrm{CA}$ & 8516 & 9875646 & 0.862 \\
\hline & Costa Rica & $\mathrm{CR}$ & 560 & 51042 & 10.971 \\
\hline & Cuba & $\mathrm{CU}$ & 53 & 110863 & 0.478 \\
\hline & Dominican Republic & DO & 10 & 48099 & 0.208 \\
\hline & El Salvador & SV & 38 & 20732 & 1.833 \\
\hline & Greenland & GL & 6 & 2165159 & 0.003 \\
\hline & Guadeloupe & GP & 5 & 1697 & 2.947 \\
\hline & Guatemala & GT & 27 & 109062 & 0.248 \\
\hline & Honduras & $\mathrm{HN}$ & 38 & 112124 & 0.339 \\
\hline & Jamaica & $\mathrm{JM}$ & 76 & 10965 & 6.931 \\
\hline & Mexico & MX & 7554 & 1949527 & 3.875 \\
\hline & Netherlands Antilles & AN & 4 & 790 & 5.066 \\
\hline & Nicaragua & NI & 26 & 128376 & 0.203 \\
\hline & Panama & PA & 51 & 74850 & 0.681 \\
\hline & Puerto Rico & PR & 280 & 8937 & 31.329 \\
\hline & Trinidad and Tobago & TT & 2 & 5144 & 0.389 \\
\hline & United States of America & US & 56277 & 9315946 & 6.041 \\
\hline & United States Virgin Islands & VI & 49 & 352 & 139.069 \\
\hline \multirow[t]{8}{*}{ Oceania } & Australia & AU & 42758 & 7687634 & 5.562 \\
\hline & Cook Islands & CK & 1 & 241 & 4.142 \\
\hline & Fiji & FJ & 9 & 18293 & 0.492 \\
\hline & Guam & GU & 15 & 544 & 27.579 \\
\hline & Micronesia (Federated States of) & FM & 78 & 740 & 105.397 \\
\hline & New Caledonia & $\mathrm{NC}$ & 2 & 18574 & 0.108 \\
\hline & New Zealand & $\mathrm{NZ}$ & 53 & 270415 & 0.196 \\
\hline & Palau & PW & 18 & 451 & 39.924 \\
\hline
\end{tabular}


Table C1. Continued.

\begin{tabular}{lllrrr}
\hline Continent & Country name & $\begin{array}{l}\text { ISO } \\
\text { code }\end{array}$ & $\begin{array}{r}\text { No. of } \\
\text { profiles }\end{array}$ & $\begin{array}{r}\text { Area } \\
\left(\mathrm{km}^{2}\right)\end{array}$ & $\begin{array}{r}\text { Profile density } \\
\left(\text { per } 1000 \mathrm{~km}^{2}\right)\end{array}$ \\
\hline & Papua New Guinea & PG & 31 & 462230 & 0.067 \\
& Samoa & WS & 17 & 2835 & 5.996 \\
& Solomon Islands & SB & 1 & 28264 & 0.035 \\
& Vanuatu & VU & 1 & 12236 & 0.082 \\
\hline South America & Argentina & AR & 244 & 2780175 & 0.088 \\
& Bolivia & BO & 86 & 1084491 & 0.079 \\
& Brazil & BR & 8883 & 8485946 & 1.047 \\
& Chile & CL & 72 & 753355 & 0.096 \\
& Colombia & CO & 237 & 1137939 & 0.208 \\
Ecuador & EC & 94 & 256249 & 0.367 \\
& French Guiana & GF & 30 & 83295 & 0.36 \\
Guyana & GY & 43 & 211722 & 0.203 \\
& Paraguay & PY & 1 & 399349 & 0.003 \\
Peru & PE & 159 & 1290640 & 0.123 \\
Suriname & SR & 31 & 145100 & 0.214 \\
& Uruguay & UY & 132 & 177811 & 0.742 \\
Venezuela & VE & 206 & 912025 & 0.226 \\
\hline
\end{tabular}

* Disputed territories. Country names and areas are based on the Global Administrative Layers (GAUL) database; see http://www.fao.org/geonetwork/srv/en/metadata.show?id=12691 (last access: 8 January 2020). 
Appendix D: Distribution of soil profiles by eco-region and by biome

Table D1. Number of soil profiles by broad rainfall and temperature zone*.

\begin{tabular}{|c|c|c|}
\hline \multirow[t]{2}{*}{ Bioclimate } & \multicolumn{2}{|c|}{ Profiles } \\
\hline & $n$ & $\%$ \\
\hline Arctic & 2 & 0.00 \\
\hline \multicolumn{3}{|l|}{ Very cold: } \\
\hline $\begin{array}{l}\text { - Dry } \\
\text { - Semi-dry } \\
\text { - Moist } \\
\text { - Wet } \\
\text { - Very wet }\end{array}$ & $\begin{array}{r}6 \\
139 \\
366 \\
1839 \\
949\end{array}$ & $\begin{array}{l}0.00 \\
0.07 \\
0.19 \\
0.94 \\
0.48\end{array}$ \\
\hline \multicolumn{3}{|l|}{ Cold: } \\
\hline $\begin{array}{l}\text { - Dry } \\
\text { - Semi-dry } \\
\text { - Moist } \\
\text { - Wet } \\
\text { - Very wet }\end{array}$ & $\begin{array}{r}9 \\
537 \\
2048 \\
10921 \\
5871\end{array}$ & $\begin{array}{l}0.00 \\
0.27 \\
1.04 \\
5.56 \\
2.99\end{array}$ \\
\hline \multicolumn{3}{|l|}{ Cool: } \\
\hline $\begin{array}{l}\text { - Very dry } \\
\text { - Dry } \\
\text { - Semi-dry } \\
\text { - Moist } \\
\text { - Wet } \\
\text { - Very wet }\end{array}$ & $\begin{array}{r}9 \\
217 \\
7098 \\
4308 \\
32927 \\
6186\end{array}$ & $\begin{array}{r}0.00 \\
0.11 \\
3.61 \\
2.19 \\
16.76 \\
3.15\end{array}$ \\
\hline \multicolumn{3}{|l|}{ Warm: } \\
\hline $\begin{array}{l}\text { - Very dry } \\
\text { - Dry } \\
\text { - Semi-dry } \\
\text { - Moist } \\
\text { - Wet } \\
\text { - Very wet }\end{array}$ & $\begin{array}{r}25 \\
1007 \\
14778 \\
6860 \\
28595 \\
853 \\
\end{array}$ & $\begin{array}{r}0.01 \\
0.51 \\
7.52 \\
3.49 \\
14.55 \\
0.43\end{array}$ \\
\hline \multicolumn{3}{|l|}{ Hot: } \\
\hline $\begin{array}{l}\text { - Very dry } \\
\text { - Dry } \\
\text { - Semi-dry } \\
\text { - Moist } \\
\text { - Wet } \\
\text { - Very wet }\end{array}$ & $\begin{array}{r}40 \\
2047 \\
14774 \\
5783 \\
18646 \\
2411 \\
\end{array}$ & $\begin{array}{l}0.02 \\
1.04 \\
7.52 \\
2.94 \\
9.49 \\
1.23\end{array}$ \\
\hline \multicolumn{3}{|l|}{ Very hot: } \\
\hline $\begin{array}{l}\text { - Very dry } \\
\text { - Dry } \\
\text { - Semi-dry } \\
\text { - Moist } \\
\text { - Wet } \\
\text { - Very wet }\end{array}$ & $\begin{array}{r}20 \\
566 \\
7727 \\
4935 \\
8895 \\
3199\end{array}$ & $\begin{array}{l}0.01 \\
0.29 \\
3.93 \\
2.51 \\
4.53 \\
1.63\end{array}$ \\
\hline No data & 1905 & 0.97 \\
\hline
\end{tabular}

Table D2. Number of soil profiles by biome*.

\begin{tabular}{lrr}
\hline Biome & \multicolumn{2}{c}{ Soil profiles } \\
\cline { 2 - 3 } & $n$ & $\%$ \\
\hline Boreal forests/taiga & 6129 & 3.1 \\
Deserts and xeric shrublands & 10212 & 5.2 \\
Flooded grasslands and savannas & 779 & 0.4 \\
Mangroves & 682 & 0.3 \\
Mediterranean forests, woodlands and scrub & 16759 & 8.5 \\
Montane grasslands and shrublands & 1402 & 0.7 \\
Temperate broadleaf and mixed forests & 63912 & 32.5 \\
Temperate conifer forests & 12153 & 6.2 \\
Temperate grasslands, savannas and shrublands & 25357 & 12.9 \\
Tropical and subtropical coniferous forests & 1354 & 0.7 \\
Tropical and subtropical dry broadleaf forests & 3808 & 1.9 \\
Tropical and subtropical grasslands, savannas and shrublands & 34779 & 17.7 \\
Tropical and subtropical moist broadleaf forests & 16492 & 8.4 \\
Tundra & 1977 & 1.0 \\
No data & 703 & 0.4 \\
\hline
\end{tabular}

* Biomes defined according to "Terrestrial Ecoregions of the World" (TEOW) (D. M. Olson et al., 2001). 
Author contributions. NB led the DATA (WoSIS) project and wrote the body of the paper. ER provided special expertise on database management and AO on soil analytical methods. All coauthors contributed to the writing and revision of this paper.

Competing interests. The authors declare that they have no conflict of interest.

Acknowledgements. The development of WoSIS has been made possible thanks to the contributions and shared knowledge of a steadily growing number of data providers, including soil survey organisations, research institutes and individual experts, for which we are grateful; for an overview, please see https://www.isric.org/ explore/wosis/wosis-contributing-institutions-and-experts (last access: 8 January 2020). We thank our colleagues Laura Poggio, Luis de Sousa and Bas Kempen for their constructive comments on a "pre-release" of the snapshot data. Further, the manuscript benefitted from the constructive comments provided by the two reviewers.

Financial support. ISRIC - World Soil Information, legally registered as the International Soil Reference and Information Centre, receives core funding from the Dutch Government.

Review statement. This paper was edited by David Carlson and reviewed by Alessandro Samuel-Rosa and one anonymous referee.

\section{References}

Al-Shammary, A. A. G., Kouzani, A. Z., Kaynak, A., Khoo, S. Y., Norton, M., and Gates, W.: Soil Bulk Density Estimation Methods: A Review, Pedosphere, 28, 581-596, https://doi.org/10.1016/S1002-0160(18)60034-7, 2018.

Arrouays, D., Leenaars, J. G. B., Richer-de-Forges, A. C., Adhikari, K., Ballabio, C., Greve, M., Grundy, M., Guerrero, E., Hempel, J., Hengl, T., Heuvelink, G., Batjes, N., Carvalho, E., Hartemink, A., Hewitt, A., Hong, S.-Y., Krasilnikov, P., Lagacherie, P., Lelyk, G., Libohova, Z., Lilly, A., McBratney, A., McKenzie, N., Vasquez, G. M., Mulder, V. L., Minasny, B., Montanarella, L., Odeh, I., Padarian, J., Poggio, L., Roudier, P., Saby, N., Savin, I., Searle, R., Solbovoy, V., Thompson, J., Smith, S., Sulaeman, Y., Vintila, R., Rossel, R. V., Wilson, P., Zhang, G.-L., Swerts, M., Oorts, K., Karklins, A., Feng, L., Ibelles Navarro, A. R., Levin, A., Laktionova, T., Dell'Acqua, M., Suvannang, N., Ruam, W., Prasad, J., Patil, N., Husnjak, S., Pásztor, L., Okx, J., Hallet, S., Keay, C., Farewell, T., Lilja, H., Juilleret, J., Marx, S., Takata, Y., Kazuyuki, Y., Mansuy, N., Panagos, P., Van Liedekerke, M., Skalsky, R., Sobocka, J., Kobza, J., Eftekhari, K., Alavipanah, S. K., Moussadek, R., Badraoui, M., Da Silva, M., Paterson, G., Gonçalves, M. d. C., Theocharopoulos, S., Yemefack, M., Tedou, S., Vrscaj, B., Grob, U., Kozák, J., Boruvka, L., Dobos, E., Taboada, M., Moretti, L., and Rodriguez, D.: Soil legacy data rescue via GlobalSoilMap and other international and national initiatives, GeoResJ, 14, 1-19, https://doi.org/10.1016/j.grj.2017.06.001, 2017.
Baroni, G., Zink, M., Kumar, R., Samaniego, L., and Attinger, S.: Effects of uncertainty in soil properties on simulated hydrological states and fluxes at different spatio-temporal scales, Hydrol. Earth Syst. Sci., 21, 2301-2320, https://doi.org/10.5194/hess-212301-2017, 2017.

Baritz, R., Erdogan, H., Fujii, K., Takata, Y., Nocita, M., Bussian, B., Batjes, N. H., Hempel, J., Wilson, P., and Vargas, R.: Harmonization of methods, measurements and indicators for the sustainable management and protection of soil resources (Providing mechanisms for the collation, analysis and exchange of consistent and comparable global soil data and information), Global Soil Partnership, FAO, 44 pp., 2014.

Batjes, N. H.: Harmonized soil profile data for applications at global and continental scales: updates to the WISE database, Soil Use Manage., 25, 124-127 https://doi.org/10.1111/j.14752743.2009.00202.x, (supplemental information: https://www. isric.org/sites/default/files/isric_report_2008_02.pdf, last access: 8 January 2020), 2009.

Batjes, N. H.: Harmonised soil property values for broad-scale modelling (WISE30sec) with estimates of global soil carbon stocks, Geoderma, 269, 61-68, https://doi.org/10.1016/j.geoderma.2016.01.034, 2016.

Batjes, N. H., Ribeiro, E., van Oostrum, A., Leenaars, J., Hengl, T., and Mendes de Jesus, J.: WoSIS: providing standardised soil profile data for the world, Earth Syst. Sci. Data, 9, 1-14, https://doi.org/10.5194/essd-9-1-2017, 2017.

Batjes, N. H., Ribeiro, E., and van Oostrum, A. J. M.: Standardised soil profile data for the world (WoSIS snapshot - September 2019), ISRIC WDC-Soils, https://doi.org/10.17027/isricwdcsoils.20190901, 2019.

Bridges, E. M.: Soil horizon designations: past use and future prospects, Catena, 20, 363-373, https://doi.org/10.1016/S03418162(05)80002-5, 1993.

Cressie, N. and Kornak, J.: Spatial Statistics in the Presence of Location Error with an Application to Remote Sensing of the Environment, Stat. Sci., 18, 436-456, https://projecteuclid.org:443/euclid.ss/1081443228, 2003.

Dai, Y., Shangguan, W., Wei, N., Xin, Q., Yuan, H., Zhang, S., Liu, S., Lu, X., Wang, D., and Yan, F.: A review of the global soil property maps for Earth system models, SOIL, 5, 137-158, https://doi.org/10.5194/soil-5-137-2019, 2019.

FAO: Guidelines for the description of soils, FAO, Rome, 1977.

FAO: Guidelines for soil description (4th Edn.), FAO, Rome, 97 pp., 2006.

FAO, IIASA, ISRIC, ISSCAS, and JRC: Harmonized World Soil Database (version 1.2), prepared by: Nachtergaele, F. O., van Velthuizen, H., Verelst, L., Wiberg, D., Batjes, N. H., Dijkshoorn, J. A., van Engelen, V. W. P., Fischer, G., Jones, A., Montanarella, L., Petri, M., Prieler, S., Teixeira, E., and Shi, X., Food and Agriculture Organization of the United Nations (FAO), International Institute for Applied Systems Analysis (IIASA), ISRIC - World Soil Information, Institute of Soil Science - Chinese Academy of Sciences (ISSCAS), Joint Research Centre of the European Commission (JRC), Laxenburg, Austria, 2012.

FAO-ISRIC: Guidelines for soil description, 3rd Edn., Rev., FAO, Rome, 70 pp., 1986.

Finke, P.: Quality assessment of digital soil maps: producers and users perspectives, in: Digital soil mapping: An introductory per- 
spective, edited by: Lagacherie, P., McBratney, A., and Voltz, M., Elsevier, Amsterdam, 523-541, 2006.

Folberth, C., Skalsky, R., Moltchanova, E., Balkovic, J., Azevedo, L. B., Obersteiner, M., and van der Velde, M.: Uncertainty in soil data can outweigh climate impact signals in global crop yield simulations, Nat. Commun., 7, 11872, https://doi.org/10.1038/ncomms11872, 2016.

Gerasimova, M. I., Lebedeva, I. I., and Khitrov, N. B.: Soil horizon designation: State of the art, problems, and proposals, Eurasian Soil Sci., 46, 599-609, https://doi.org/10.1134/S1064229313050037, 2013.

GlobalSoilMap: Specifications Tiered GlobalSoilMap products (Release 2.4), 52 pp., 2015.

Grimm, R. and Behrens, T.: Uncertainty analysis of sample locations within digital soil mapping approaches, Geoderma, 155, 154-163, https://doi.org/10.1016/j.geoderma.2009.05.006, 2010.

GSP Pillar 4 Working Group: Towards the implementation of GloSIS through a Country Soil Information Systems (CountrySIS) Framework (Concept Note, draft), available at: http://www.fao.org/global-soil-partnership/pillars-action/ 4-information-data/glosis/en/, last access: 26 November 2018.

Guevara, M., Olmedo, G. F., Stell, E., Yigini, Y., Aguilar Duarte, Y., Arellano Hernández, C., Arévalo, G. E., Arroyo-Cruz, C. E., Bolivar, A., Bunning, S., Bustamante Cañas, N., Cruz-Gaistardo, C. O., Davila, F., Dell Acqua, M., Encina, A., Figueredo Tacona, H., Fontes, F., Hernández Herrera, J. A., Ibelles Navarro, A. R., Loayza, V., Manueles, A. M., Mendoza Jara, F., Olivera, C., Osorio Hermosilla, R., Pereira, G., Prieto, P., Ramos, I. A., Rey Brina, J. C., Rivera, R., Rodríguez-Rodríguez, J., Roopnarine, R., Rosales Ibarra, A., Rosales Riveiro, K. A., Schulz, G. A., Spence, A., Vasques, G. M., Vargas, R. R., and Vargas, R.: No silver bullet for digital soil mapping: country-specific soil organic carbon estimates across Latin America, SOIL, 4, 173-193, https://doi.org/10.5194/soil-4-173-2018, 2018.

Hendriks, C. M. J., Stoorvogel, J. J., and Claessens, L.: Exploring the challenges with soil data in regional land use analysis, Agr. Syst., 144, 9-21, https://doi.org/10.1016/j.agsy.2016.01.007, 2016.

Hengl, T., Leenaars, J. G. B., Shepherd, K. D., Walsh, M. G., Heuvelink, G. B. M., Mamo, T., Tilahun, H., Berkhout, E., Cooper, M., Fegraus, E., Wheeler, I., and Kwabena, N. A.: Soil nutrient maps of Sub-Saharan Africa: assessment of soil nutrient content at $250 \mathrm{~m}$ spatial resolution using machine learning, Nutr. Cycl. Agroecosys., 109, 77-102, https://doi.org/10.1007/s10705-017-9870-x, 2017a.

Hengl, T., Mendes de Jesus, J., Heuvelink, G. B. M., Ruiperez Gonzalez, M., Kilibarda, M., Blagotić, A., Shangguan, W., Wright, M. N., Geng, X., Bauer-Marschallinger, B., Guevara, M. A., Vargas, R., MacMillan, R. A., Batjes, N. H., Leenaars, J. G. B., Ribeiro, E., Wheeler, I., Mantel, S., and Kempen, B.: SoilGrids250m: Global gridded soil information based on machine learning, PLoS ONE, 12, e0169748, https://doi.org/10.1371/journal.pone.0169748, 2017b.

Heuvelink, G. B. M.: Uncertainty quantification of GlobalSoilMap products in: GlobalSoilMap. Basis of the Global Spatial Soil Information System, edited by: Arrouays, D., McKenzie, N., Hempel, J., Forges, A. R. D., and McBratney, A., Taylor \& Francis Group, London, UK, 335-240, 2014.
Heuvelink, G. B. M. and Brown, J. D.: Towards a soil information system for uncertain soil data in: Digital soil mapping: An introductory perspective, edited by: Lagacherie, P., McBratney, A., and Voltz, M., Elsevier, Amsterdam, 97-106, 2006.

INSPIRE: Data specifications - Infrastructure for spatial information in the European Community, available at: http://inspire.ec. europa.eu/index.cfm/pageid/2 (last access: 25 April 2016), 2015.

ISO-28258: Soil quality - Digital exchange of soil-related data, available at: https://www.iso.org/obp/ui\#iso:std:iso:28258:ed-1: v1:en (last access: 31 January 2018), 2013.

ISRIC: Data and Software Policy: available at: http://www.isric.org/ sites/default/files/ISRIC_Data_Policy_2016jun21.pdf (last accesss: 15 May 2019), 2016.

IUSS Working Group WRB: World Reference Base for Soil Resources (2nd Edn.), FAO, Rome, World Soil Resources Report 103, 145 pp., 2006.

IUSS Working Group WRB: World Reference Base for soil resources 2014 - International soil classification system for naming soils and creating legends for soil maps (update 2015), Global Soil Partnership, International Union of Soil Sciences, and Food and Agriculture Organization of the United Nations, Rome, World Soil Resources Reports 106, 182 pp., 2015.

Kalra, Y. P. and Maynard, D. G.: Methods manual for forest soil and plant analysis, Forestry Canada, Edmonton (Alberta), 116 pp., 1991.

Leenaars, J. G. B., van Oostrum, A. J. M., and Ruiperez Gonzalez, M.: Africa Soil Profiles Database: A compilation of georeferenced and standardised legacy soil profile data for Sub Saharan Africa (version 1.2), Africa Soil Information Service (AfSIS) and ISRIC - World Soil Information, Wageningen, Report 2014/01, 160 pp., 2014.

Leenaars, J. G. B., Claessens, L., Heuvelink, G. B. M., Hengl, T., Ruiperez González, M., van Bussel, L. G. J., Guilpart, N., Yang, H., and Cassman, K. G.: Mapping rootable depth and root zone plant-available water holding capacity of the soil of sub-Saharan Africa, Geoderma, 324, 18-36, https://doi.org/10.1016/j.geoderma.2018.02.046, 2018.

Lutz, F., Stoorvogel, J. J., and Müller, C.: Options to model the effects of tillage on $\mathrm{N}_{2} \mathrm{O}$ emissions at the global scale, Ecol. Model., 392, 212-225, 2019.

Magnusson, B. and Örnemark, U.: The Fitness for Purpose of Analytical Methods - A Laboratory Guide to Method Validation and Related Topics (2nd Edn.), available at: http://www.eurachem. org (last access: 8 September 2019), 2014.

Maire, V., Wright, I. J., Prentice, I. C., Batjes, N. H., Bhaskar, R., van Bodegom, P. M., Cornwell, W. K., Ellsworth, D., Niinemets, Ü., Ordonez, A., Reich, P. B., and Santiago, L. S.: Global effects of soil and climate on leaf photosynthetic traits and rates, Global Ecol. Biogeogr., 24, 706-715, https://doi.org/10.1111/geb.12296, 2015.

Malhotra, A., Todd-Brown, K., Nave, L. E., Batjes, N. H., Holmquist, J. R., Hoyt, A. M., Iversen, C. M., Jackson, R. B., Lajtha, K., Lawrence, C., Vindušková, O., Wieder, W., Williams, M., Hugelius, G., and Harden, J.: The landscape of soil carbon data: emerging questions, synergies and databases, Prog. Phys. Geog., 43, 707-719, https://doi.org/10.1177/0309133319873309, 2019.

Moulatlet, G. M., Zuquim, G., Figueiredo, F. O. G., Lehtonen, S., Emilio, T., Ruokolainen, K., and Tuomisto, H.: Using dig- 
ital soil maps to infer edaphic affinities of plant species in Amazonia: Problems and prospects, Ecol. Evol., 7, 8463-8477, https://doi.org/10.1002/ece3.3242, 2017.

Munzert, M., Kießling, G., Übelhör, W., Nätscher, L., and Neubert, K.-H.: Expanded measurement uncertainty of soil parameters derived from proficiency-testing data, J. Plant Nutr. Soil Sci., 170, 722-728, https://doi.org/10.1002/jpln.200620701, 2007.

Nave, L., Johnson, K., van Ingen, C., Agarwal, D., Humphrey, M., and Beekwilder, N.: ISCN Database V3-1, https://doi.org/10.17040/ISCN/1305039, 2017.

OGC: Soil Data IE (Interoperability Experiment), available at: https://www.opengeospatial.org/projects/initiatives/soildataie, last access: 14 June 2019.

Olson, D. M., Dinerstein, E., Wikramanayake, E. D., Burgess, N. D., Powell, G. V. N., Underwood, E. C., D'amico, J. A., Itoua, I., Strand, H. E., Morrison, J. C., Loucks, C. J., Allnutt, T. F., Ricketts, T. H., Kura, Y., Lamoreux, J. F., Wettengel, W. W., Hedao, P., and Kassem, K. R.: Terrestrial Ecoregions of the World: A New Map of Life on Earth: A new global map of terrestrial ecoregions provides an innovative tool for conserving biodiversity, BioScience, 51, 933-938, https://doi.org/10.1641/00063568(2001)051[0933:TEOTWA]2.0.CO;2, 2001.

Olson, R. J., Johnson, K. R., Zheng, D. L., and Scurlock, J. M. O.: Global and regional ecosystem modelling: databases of model drivers and validation measurements, Oak Ridge National Laboratory, Oak Ridge, ORNL/TM-2001/196, 95 pp., 2001.

Orgiazzi, A., Ballabio, C., Panagos, P., Jones, A., and FernándezUgalde, O.: LUCAS Soil, the largest expandable soil dataset for Europe: a review, Eur. J. Soil Sci., 69, 140-153, https://doi.org/10.1111/ejss.12499, 2018.

Rayment, E. R. and Lyons, D. J.: Soil chemical methods - Australasia, CSIRO Publishing, 495 pp., 2011.

Ribeiro, E., Batjes, N. H., and Van Oostrum, A. J. M.: World Soil Information Service (WoSIS) - Towards the standardization and harmonization of world soil data, Procedures Manual 2018, ISRIC - World Soil Information, Wageningen, ISRIC Report 2018/01, 166 pp., 2018.

Rossel, R. A. V. and McBratney, A. B.: Soil chemical analytical accuracy and costs: implications from precision agriculture, Aust. J. Exp. Agr., 38, 765-775, https://doi.org/10.1071/EA97158, 1998.

Rossiter, D.: Accessing WoSIS from R - "Snapshot" version, available at: https://www.isric.org/sites/default/files/WoSIS_ Snapshot_With_R_2.pdf (last access: 30 January 2020), 2019.

Sanderman, J., Hengl, T., and Fiske, G. J.: Soil carbon debt of 12,000 years of human land use, P. Natl. Acad. Sci. USA, 36, 9575-9580, https://doi.org/10.1073/pnas.1706103114, 2017.

Sayre, R., Dangermond, J., Frye, C., Vaughan, R., Aniello, P., Breyer, S., Cribbs, D., Hopkins, D., Nauman, R., Derrenbacher, W., Burton, D., Grosse, A., True, D., Metzger, M., Hartmann, J., Moosdorf, N., Dürr, H., Paganini, M., DeFourny, P., Arino, O., and Maynard, S.: A New Map of Global Ecological Land Units - An Ecophysiographic Stratification Approach, Association of American Geographers, Washington DC, 46 pp., 2014.

Schoeneberger, P. J., Wysocki, D. A., Benham, E. C., and Soil Survey Staff: Field book for describing and sampling soils (ver. 3.0), National Soil Survey Center Natural Resources Conservation Service, U.S. Department of Agriculture, Lincoln (NE), 2012.
Soil Survey Staff: Soil Survey Laboratory Information Manual (Ver. 2.0), National Soil Survey Center, Soil Survey Laboratory, USDA-NRCS, Lincoln (NE), Soil Survey Investigation Report No. 45, 506 pp., 2011.

Soil Survey Staff: Kellogg Soil Survey Laboratory Methods Manual, Version 5.0, edited by: Burt, R. and Soil Survey Staff, U.S. Department of Agriculture, Natural Resources Conservation Service, Lincoln (Nebraska), 1001 pp., 2014a.

Soil Survey Staff: Keys to Soil Taxonomy, 12th Edn., USDANatural Resources Conservation Service, Washington, DC, 2014b.

Suvannang, N., Hartmann, C., Yakimenko, O., Solokha, M., Bertsch, F., and Moody, P.: Evaluation of the First Global Soil Laboratory Network (GLOSOLAN) online survey for assessing soil laboratory capacities, Global Soil Partnership (GSP)/Food and Agriculture Organization of the United Nations (FAO), Rome, GLOSOLAN/18/Survey Report, 54 pp., 2018.

Terhoeven-Urselmans, T., Shepherd, K. D., Chabrillat, S., and BenDor, E.: Application of a global soil spectral library as tool for soil quality assessment in Sub-Saharan Africa, A EUFAR Workshop on Quantitative Applications of Soil Spectroscopy, p. 15, 5-16 April 2010.

Tóth, G., Jones, A., and Montanarella, L.: LUCAS Topsoil survey: methodology, data and results Land Resource Management Unit - Soil Action, European Commission Joint Research Centre Institute for Environment and Sustainability, 141 pp., 2013.

USDA-NCSS: National Cooperative Soil Survey (NCSS) Soil Characterization Database, United States Department of Agriculture, Natural Resources Conservation Service, Lincoln, 2018.

van Engelen, V. W. P. and Dijkshoorn, J. A.: Global and National Soils and Terrain Digital Databases (SOTER) - Procedures manual (Ver. 2.0), IUSS, ISRIC and FAO, Wageningen, ISRIC Report 2013/04, 198 pp., 2013.

van Ittersum, M. K., Cassman, K. G., Grassini, P., Wolf, J., Tittonell, P., and Hochman, Z.: Yield gap analysis with local to global relevance - A review, Field Crop. Res., 143, 4-17, 2013.

Van Looy, K., Bouma, J., Herbst, M., Koestel, J., Minasny, B., Mishra, U., Montzka, C., Nemes, A., Pachepsky, Y., Padarian, J., Schaap, M., Tóth, B., Verhoef, A., Vanderborght, J., van der Ploeg, M., Weihermüller, L., Zacharias, S., Zhang, Y., and Vereecken, H. C. R. G.: Pedotransfer functions in Earth system science: challenges and perspectives, Rev. Geophys., 55, 1199 1256, https://doi.org/10.1002/2017RG000581, 2017.

van Reeuwijk, L. P.: On the way to improve international soil classification and correlation: the variability of soil analytical data, ISRIC, Wageningen, Annual Report 1983, 7-13, 1983.

van Reeuwijk, L. P.: Guidelines for quality management in soil and plant laboratories, FAO, Rome, 143 pp., 1998.

Viscarra Rossel, R. A., Behrens, T., Ben-Dor, E., Brown, D. J., Demattê, J. A. M., Shepherd, K. D., Shi, Z., Stenberg, B., Stevens, A., Adamchuk, V., Aïchi, H., Barthès, B. G., Bartholomeus, H. M., Bayer, A. D., Bernoux, M., Böttcher, K., Brodský, L., Du, C. W., Chappell, A., Fouad, Y., Genot, V., Gomez, C., Grunwald, S., Gubler, A., Guerrero, C., Hedley, C. B., Knadel, M., Morrás, H. J. M., Nocita, M., Ramirez-Lopez, L., Roudier, P., Campos, E. M. R., Sanborn, P., Sellitto, V. M., Sudduth, K. A., Rawlins, B. G., Walter, C., Winowiecki, L. A., Hong, S. Y., and Ji, W.: A global spectral library to 
characterize the world's soil, Earth-Sci. Rev., 155, 198-230, https://doi.org/10.1016/j.earscirev.2016.01.012, 2016.

WEPAL: ISE Reference Material - A list with all available ISE reference material samples, WEPAL (Wageningen Evaluating Programmes for Analytical Laboratories), Wageningen, 110 pp., 2019.

Wilkinson, M. D., Dumontier, M., Aalbersberg, I. J., Appleton, G., Axton, M., Baak, A., Blomberg, N., Boiten, J.-W., da Silva Santos, L. B., Bourne, P. E., Bouwman, J., Brookes, A. J., Clark, T., Crosas, M., Dillo, I., Dumon, O., Edmunds, S., Evelo, C. T., Finkers, R., Gonzalez-Beltran, A., Gray, A. J. G., Groth, P., Goble, C., Grethe, J. S., Heringa, J., 't Hoen, P. A. C., Hooft, R., Kuhn, T., Kok, R., Kok, J., Lusher, S. J., Martone, M. E., Mons, A., Packer, A. L., Persson, B., Rocca-Serra, P., Roos, M., van Schaik, R., Sansone, S.-A., Schultes, E., Sengstag, T., Slater, T., Strawn, G., Swertz, M. A., Thompson, M., van der Lei, J., van Mulligen, E., Velterop, J., Waagmeester, A., Wittenburg, P., Wolstencroft, K., Zhao, J., and Mons, B.: The FAIR Guiding Principles for scientific data management and stewardship, Scientific Data, 3, 160018, https://doi.org/10.1038/sdata.2016.18, 2016. 